\title{
Strategies to Deliver Peptide Drugs to the Brain
}

\section{Aikaterini Lalatsa ${ }^{1}$, Andreas G. Schatzlein ${ }^{2,3}$, ljeoma F. Uchegbu ${ }^{2,3} \dagger$}

${ }^{1}$ Department of Pharmaceutics, School of Pharmacy and Biomedical Sciences, University of Portsmouth, St Michael's Building 5.05, White Swan Road, Portsmouth, PO1 2DT, U. K.

${ }^{2}$ UCL School of Pharmacy, 29-39 Brunswick Square, London, U. K.

${ }^{3}$ Nanomerics, Ltd., Approach Road, St Albans, UK.

†Author for correspondence: Tel: +44 207753 5997, Fax: +44 207753 5942, Email: ijeoma.uchegbu@ucl.ac.uk

\section{Keywords}

Peptides, brain delivery, blood brain barrier, opioid peptides, neurodegenerative diseases, intravenous, oral, intranasal, receptor mediated endocytosis, nanoparticles, cell penetrating peptides 


\section{Abstract}

Neurological diseases such as neurodegeneration, pain, psychiatric disorders, stroke and brain cancers would greatly benefit from the use of highly potent and specific peptide pharmaceuticals. Peptides are especially desirable because of their low inherent toxicity. The presence of the blood-brain barrier (BBB), their short duration of action and need for parenteral administration limits their clinical use. However, over the last decade there have been significant advances in delivering peptides to the central nervous system. Angiopep peptides developed by Angiochem, transferrin antibodies developed by Armagen and cell penetrating peptides have all shown promise in delivering therapeutic peptides across the BBB after intravenous administration. Non-invasive methods of delivering peptides to the brain include the use of chitosan amphiphilie nanoparticles for oral delivery and nose to brain strategies. The uptake of the chitosan amphiphile nanoparticles by the gastrointestinal epithelium is important for oral peptide delivery. Finally protecting peptides from plasma degradation is integral to the success of most of these peptide delivery strategies. 


\section{Table of Contents Graphic}

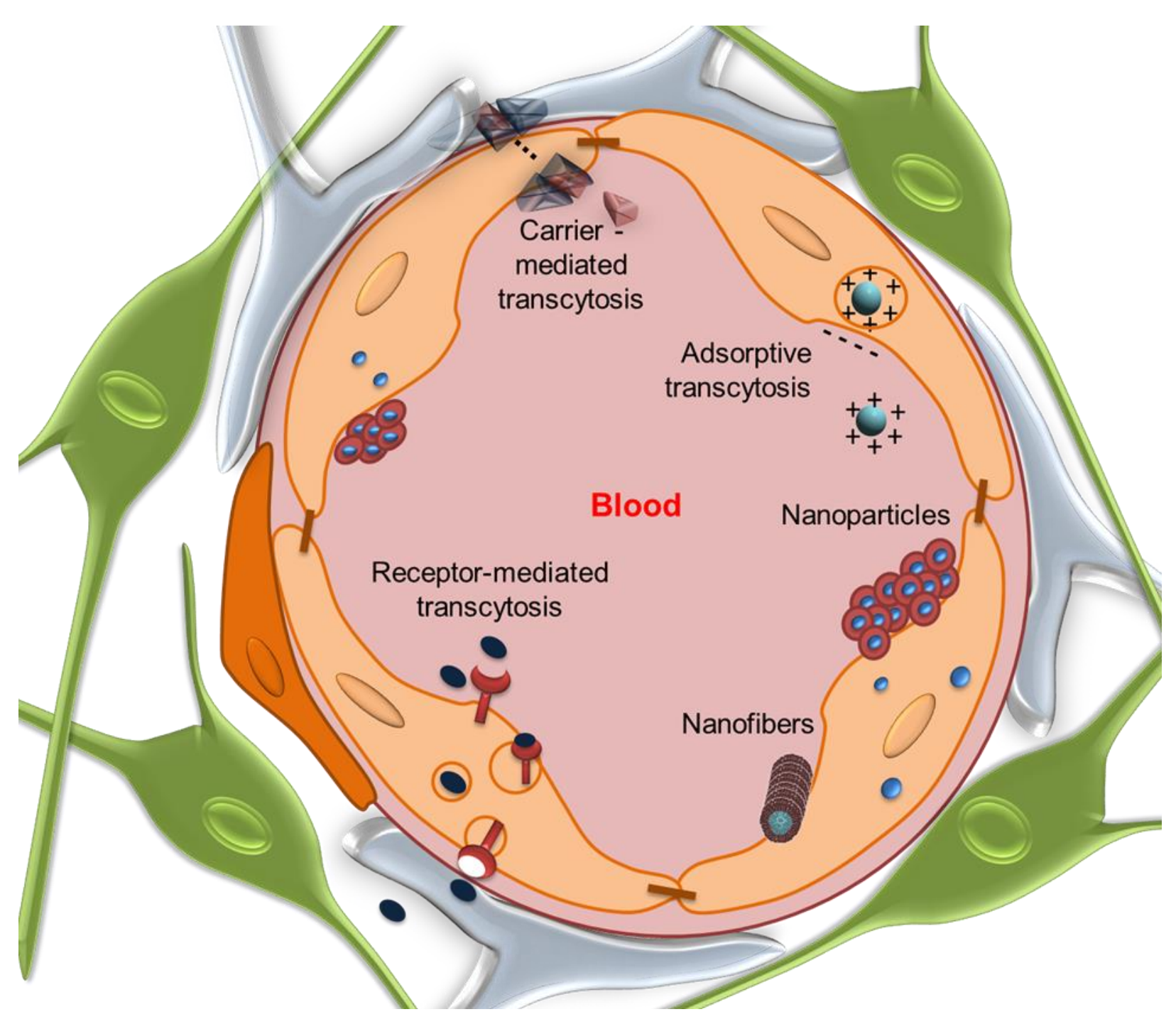




\subsection{Introduction}

Peptides, proteins and antibodies are of increasing interest to the pharmaceutical industry due to their high potency and selectivity (Serrano Lopez and Lalatsa 2013). Peptides biodegrade into non-toxic metabolites, possess a minimal potential for drug-drug interactions and are less likely to cause an immunogenic reaction when compared to larger proteins (Van der Walle 2011). These favourable properties have resulted in peptides having a relatively good probability of securing regulatory approval, when compared to low molecular weight drugs (Lax 2010).

Today the most significant impediment to translating peptides into viable therapies is their overwhelming need for parenteral administration and their short duration of action. Peptides, despite their excellent pharmacological properties, are molecules with poor physical and metabolic stability and peptides have a limited ability to permeate biological membranes; the latter due to their hydrophilicity and comparatively high molecular weight (> $500 \mathrm{Da})$. However, despite these limitations, the decreasing number of low molecular weight drugs being approved for clinical use has resulted in an intensification in efforts to find suitable delivery strategies for peptides; delivery strategies that would enable peptides to be converted into medicines. It is interesting to note that peptides now make up $10 \%$ of the world's pharmaceutical sales revenues (Reichert 2010).

Brain diseases would benefit from the use of highly potent and specific pharmaceuticals with low inherent toxicity and several peptides are being investigated as therapies for neurological diseases, such as neurodegeneration, pain, psychiatric disorders, stroke and brain cancers (Strand 2003). These neurological diseases are responsible for more than $12 \%$ of total global deaths (Masserini 2013). However for viable peptide neurotherapies to emerge, peptides need to cross the blood brain barrier (BBB) to elicit their response. The BBB, evolutionary designed to maintain brain homeostasis and protect the brain from 
circulating toxins, prevents over 95\% of drugs from accessing the brain (Pardridge 2005). Furthermore, the short plasma half life of most peptides means that virtually no peptides show any real brain bioavailability, unless they are transported via specific carriers. As such there are currently no neuropeptide drugs on the market. In essence the delivery of peptides to the brain today would require the use of extremely invasive techniques such as intracerebroventricular infusion, convection-enhanced delivery (Zhou, Patel et al. 2013), intracerebral injections, the use of intracranial implants or temporary disruption of the BBB by using osmotic agents, ultrasound or by the activation of the bradykinin B2 receptors (Gabathuler 2010).

Nanoparticle technologies are not widely used in medicine, despite the notable exceptions provided by medicines such as Ambisome, Doxil and Abraxane (Uchegbu and Siew 2013). The complexity of nanoparticles as multi-component three dimensional constructs requiring careful design and engineering, detailed analytical methods and reproducible scale-up manufacturing processes to achieve a consistent product with the intended physicochemical, biological and pharmacological properties along with the lack of regulatory standards in the examination of nanomedicines are hindering their translation into the clinic. However preclinical studies abound in which nanoparticles have shown promise in meeting the challenge of peptide delivery (Lalatsa, Schatzlein et al. 2012). The reasons for the use of nanoparticles to deliver peptides across the blood brain barrier include their small size, which promotes blood residence and hence brain transport of the encapsulated drug (Lalatsa, Lee et al. 2012; Nance, Woodworth et al. 2012), particle shape as nanofibres have been shown to deliver peptides across the blood brain barrier (Mazza, Notman et al. 2013) and the fact that nanoparticle surfaces may be decorated with various transport ligands to exploit a number of brain endothelial transporters such as: the low density lipoprotein (LDL) receptor related protein $1 \& 2$, and the transferrin, leptin, insulin and diphtheria toxin receptors (Lalatsa, Schatzlein et al. 2012; Pardridge 2012; Pardridge and Boado 2012). This 
review focuses on recent advances in peptide brain delivery with a particular emphasis on the use of nanoparticle technologies. Peptides, for the purposes of this review, are defined as polyamino acid bioactive agents with less than 60 amino acids.

\subsection{Pathways for the transport of peptides across the blood brain}

\section{barrier}

There are several potential routes by which peptides could cross the blood brain barrier, namely by diffusion, carrier mediated uptake and receptor mediated endocytosis (Figure 1). For diffusion, enhanced lipophilicity is required and for receptor mediated and carrier mediated uptake a transport specific ligand must be incorporated within the peptide medicine.

Weak hydrogen bonding potential (less than 6 hydrogen bonds), lipophilicity (Log D $>2$ ) and a small molecular size $(<500 \mathrm{Da})$ along with the absence of free rotatable bonds and a polar surface area of $<60-70 \AA$ are favourable for permeation across the BBB via diffusion (Pauletti, Okumu et al. 1997; Sorensen, Steenberg et al. 1997; Kelder, Grootenhuis et al. 1999; Lennernas and Lundgren 2004). Thus, passive diffusion of natural peptides is very limited unless the peptides possess an amphipathic structure (Teixido, Belda et al. 2005) or are rendered lipophilic by synthetic means (Batrakova, Vinogradov et al. 2005; Lalatsa, Lee et al. 2012).

The brain capillary endothelial cells rely upon transport proteins to facilitate the entry of essential polar nutrients with polarised expression on either the luminal or abluminal membrane (Brasnjevic, Steinbusch et al. 2009). These transport systems are specific for certain small peptides of no less than 10 amino acids (peroxisome Targeting Signal Type 15, PTS1 - 5), hexoses (glucose transporter 1, GLUT - 1), monocarboxylic acids (Protonlinked monocarboxylate transporter, MCT - 1), amino acids, organic anions (organic anion- 
transporting polypeptide, OATP) and organic cations (organic cation transporter novel subfamily, OCTN), neurotransmitters and nucleosides. Utilisation of these carrier systems expressed at the BBB is a useful strategy for therapeutic peptide delivery to the brain; however there is a need to attach specific chemical groups to the peptides in order to render them substrates for these endogenous carriers; e.g. the glycosylation of the peptide to enable transport through the GLUT - 1 receptors (Bilsky, Egleton et al. 2000; Egleton, Mitchell et al. 2000). These carrier mediated strategies of peptide transport have been recently reviewed (Brasnjevic, Steinbusch et al. 2009; Lalatsa 2011; Lalatsa, Schatzlein et al. 2012) and the carrier system for glutathione (GSH), which is present at the luminal membrane is the only carrier mediated system that has been used for the delivery of nanoparticles (Cacciatore, Baldassarre et al. 2012).

Endocytosis is the main route of cellular entry for large molecular weight compounds and several peptides have been transported across the BBB via receptor mediated transcytosis (Brasnjevic, Steinbusch et al. 2009). Binding of the ligand to its specific membrane receptor on the cell surface induces a modification of the receptor protein and triggers the formation of invaginations; these invaginations may be clathrin coated and in turn trigger the formation of endocytotic vesicles (Broadwell, Balin et al. 1988). Once within the cell, the ligand containing vesicles can be either exocytosed leading to transport across the BBB, fused with a lysosome leading to intracellular degradation (Broadwell, Balin et al. 1988), or can bind to a second intracellular receptor as in the case of the transfer of iron from transferrin to intracellular ferritin (Willingham, Hanover et al. 1984). Once there is dissociation of the ligand from the receptor, the receptor is recycled to the cell surface to participate in further transport events (Gabathuler 2010). Another minor intracellular pathway may involve trafficking of endosomes, containing intact receptor ligand, to the inner saccule of the Golgi complex, where the enzymes can cause dissociation of the ligand from the receptor, and the separated ligand may then be exported in vesicles destined for lysosomal degradation 
(Brasnjevic, Steinbusch et al. 2009). Exocytosis and the avoidance of the lysosomal pathway may be a special feature of the BBB compared to other types of cells and tissues, as transcytosis of a number of macromolecules is a homeostatic requirement (Abbott, Patabendige et al. 2010). Receptor-mediated endocytosis across the BBB in vivo has been shown for a few peptides such as insulin (Frank, Pardridge et al. 1986). Table 1 summarises available receptors for transport of molecules across the BBB. 

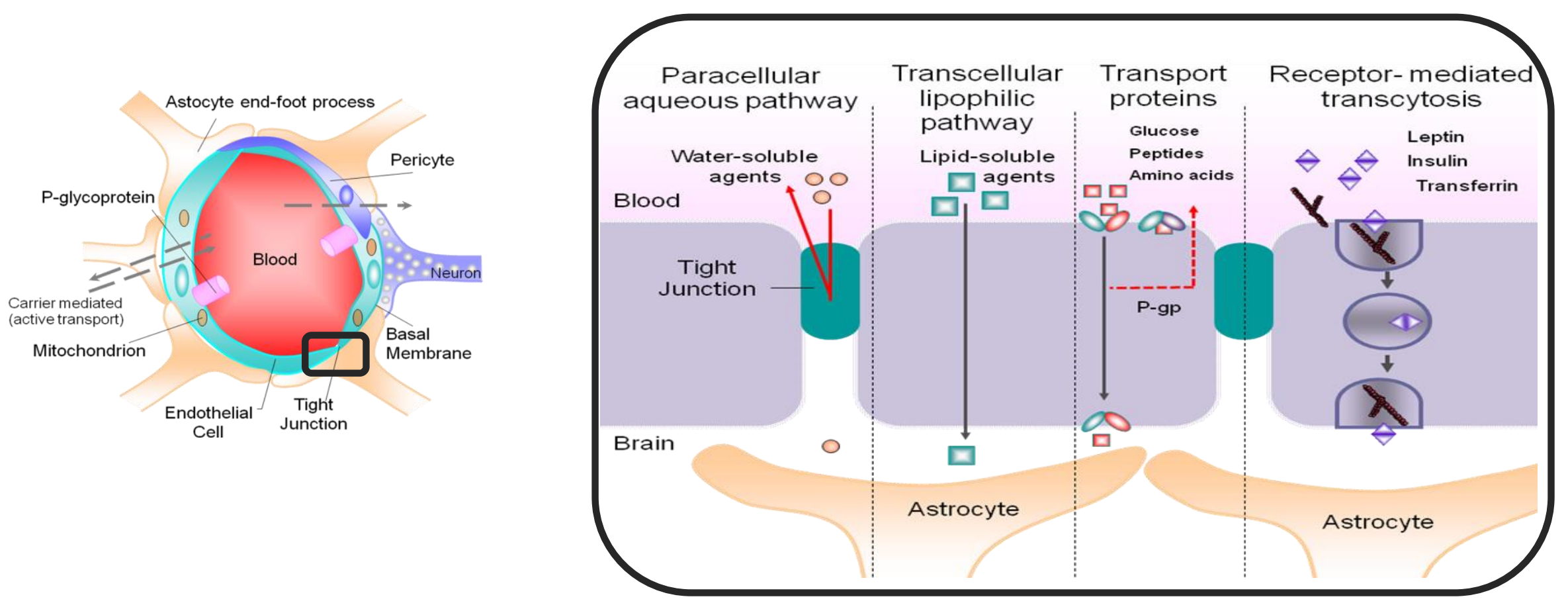

Figure 1: Schematic diagram of the neurovascular unit forming the BBB. (Right): Routes for transport across the BBB. Modified with permission from (Abbott, Patabendige et al. 2010). 
Table 1: Receptors available for transport of molecules across the BBB

\begin{tabular}{|c|c|c|c|}
\hline Receptor & Ligand & Direction & Reference \\
\hline Insulin & Insulin & $\begin{array}{l}\text { Blood to } \\
\text { Brain }\end{array}$ & $\begin{array}{l}\text { (van Houten, Posner et } \\
\text { al. 1979; Frank and } \\
\text { Pardridge 1981) }\end{array}$ \\
\hline $\begin{array}{l}\text { Insulin like growth } \\
\text { factor }\end{array}$ & $\begin{array}{l}\text { Insulin like growth factor I } \\
\text { and II }\end{array}$ & $\begin{array}{l}\text { Blood } \\
\text { Brain }\end{array}$ & $\begin{array}{l}\text { (Frank, Pardridge et al. } \\
\text { 1986; Duffy, Pardridge et } \\
\text { al. 1988) }\end{array}$ \\
\hline Transferrin & Transferrin & $\begin{array}{l}\text { Blood } \\
\text { Brain }\end{array}$ & $\begin{array}{l}\text { (Jefferies, Brandon et al. } \\
\text { 1984; Fishman, Rubin et } \\
\text { al. 1987; Visser, } \\
\text { Stevanovic et al. 2004) }\end{array}$ \\
\hline Melanotransferrin & Melanotransferrin & $\begin{array}{l}\text { Blood } \\
\text { Brain }\end{array}$ & $\begin{array}{l}\text { (Demeule, Poirier et al. } \\
\text { 2002) }\end{array}$ \\
\hline Leptin & Leptin & $\begin{array}{l}\text { Blood } \\
\text { Brain }\end{array}$ & (Banks and Farrell 2003) \\
\hline $\begin{array}{l}\text { Tumour necrosis } \\
\text { factor alpha }\end{array}$ & $\begin{array}{l}\text { Tumour necrosis factor } \\
\text { alpha }\end{array}$ & $\begin{array}{l}\text { Blood } \\
\text { Brain }\end{array}$ & (Pan and Kastin 2002) \\
\hline $\begin{array}{l}\text { Epidermal growth } \\
\text { factor }\end{array}$ & Epidermal growth factor & $\begin{array}{l}\text { Blood } \\
\text { Brain }\end{array}$ & (Pan and Kastin 1999) \\
\hline Immunoglobulin G & Immunoglobulin G & $\begin{array}{l}\text { Blood } \\
\text { Brain }\end{array}$ & $\begin{array}{l}\text { (Zlokovic, Skundric et al. } \\
1990)\end{array}$ \\
\hline
\end{tabular}




\begin{tabular}{|l|l|l|l|}
\hline Receptor & Ligand & Direction & Reference \\
\hline Interleukin & $\begin{array}{l}\text { Interleukin 1a, Interleukin } \\
\text { 1b, Interleukin 6 }\end{array}$ & Blood to & (Banks 2001; Banks, \\
& Farr et al. 2001)
\end{tabular}

The conjugation of peptide loaded nanostructures to the transport ligands shown in Table 1 is a viable strategy for the delivery of peptides to the brain (Brasnjevic, Steinbusch et al. 2009). However when choosing a transport ligand, the ligand should have certain properties:

a) it should have sufficiently high affinity for the receptor and yet still enable the release of its cargo in the brain parenchyma, b) the endogenous ligand should not compete with the delivery ligand for receptor occupancy at the BBB, thus a careful consideration of the relative binding affinities and the physiological levels of the endogenous ligand needs to be made [transferrin is not a suitable ligand as its plasma concentration is $>1000$ fold higher than the 
transferrin - transferrin receptor $\mathrm{K}_{d}(5.6 \mathrm{nM})$ (Visser, Voorwinden et al. 2004), c) the brain uptake of the ligand conjugate should be high enough to allow for a therapeutic dose to reach the brain.

\subsection{Parenteral Administration}

Due to the delivery challenges highlighted above, most experimental neuropeptides have been administered by parenteral routes, i.e. the intravenous route and in some preclinical studies via the intraperitoneal route. Once in the blood these neuropeptides are required to cross the BBB. The brain is $1 \%$ of the rodent mass and hence delivery of $1 \%$ of the injected dose to the brain at the peak time point, indicates a complete negation of the blood brain barrier in experimental studies. However such levels are rarely achieved and morphine for example, a very effective CNS drug only achieves $0.02 \%$ of the dose reaching the rodent brain 30 minutes after subcutaneous injection (Banks and Kastin 1994). Hence levels of brain delivery in excess of $0.1 \%$ of the administered dose, represent a real crossing of the blood brain barrier. A number of methods have been used to achieve brain delivery that can be summarised according to their reliance on endogenous transporters and the biological properties of the nanoparticles.

\subsection{Carrier Transport Mediated Uptake}

The glutathione carrier has been employed in delivering peptides across the BBB in the form of glutathione poly(ethylene glycol) (GSH-PEG) liposomes. When these liposomes were loaded with a synthetic opioid peptide (DAMGO, H -Tyr - d - Ala - Gly - MePhe - Gly - ol) and injected intravenously they prolonged the brain half-life of DAMGO to $6.9 \pm 2.3 \mathrm{~h}$, increasing he half life by 4.5 fold when compared to the administration of the free drug (Lindqvist, Rip et al. 2013). It was found that free DAMGO entered the brain to a limited extent and the use of the GSH - PEG liposomes doubled the brain exposure (Lindqvist, Rip et al. 2013). 


\subsection{Receptor Mediated Uptake}

\subsubsection{Low-density lipoprotein receptor related protein 1 (LRP1)}

A new family of 19 amino acid peptides derived from the kunitz domain of protease inhibitor aprotinin, and known as the Angiopeps, has been shown to facilitate transfer across the BBB by utilising low-density lipoprotein receptor related protein 1 (LRP - 1) (Demeule, Currie et al. 2008; Demeule, Regina et al. 2008). This technology has been used to deliver both peptides and larger molecules such as $150 \mathrm{kDa}$ antibodies (Gabathuler 2010). Angiopep 2's (TFFYGGSRGKRNNFKTEEY) positive charge contributes to its binding to the brain endothelial cell surface and after its interaction with LRP - 1, the Angiopep - 2 - LRP - 1 complex is internalised by vesicle formation. LRP-1 is involved in the Angiopeps' mechanism of action, and this distinguishes the Angiopeps from other positively charged peptide transporters such as the cell penetrating peptides (CPPs): transcription activating factor (TAT), penetratin and Syn - B; these CPPs utilise adsorptive-mediated transcytosis (Herve, Ghinea et al. 2008; Bertrand, Currie et al. 2010). ANG2002 is a conjugate of Angiopep - 2 peptide and neurotensin (a 13 amino acid neuropeptide). The transport of ANG2002 across the $\mathrm{BBB}$ is higher than that of unconjugated neurotensin and the conjugated neurotensin in ANG2002 retains its affinity for the neurotensin receptor (Demeule, Regina et al. 2010). Using a similar strategy, ANG2006 has been introduced and this is a conjugate of Angiopep -2 with Exendin - 4 (glucagon - like peptide - 1 agonist); however very limited information is available pertaining to this peptide conjugate (Nikolich 2009). The Angiopep technology is now at a clinical stage and ANG1005 (an Angiopep - 2 - paclitaxel conjugate) (Regina, Demeule et al. 2008; Thomas, Taskar et al. 2009; Gabathuler 2010) is currently being clinically evaluated for the delivery of paclitaxel to brain tumours.

\subsubsection{Low density lipoprotein receptor}

Vect-Horus S.A.S. (Marseille, France) recently identified a series of non-competitive peptide- 
based ligands for the human low density lipoprotein receptor (LDLR), e.g. VH0411, a 15 amino acid peptide [Ac - Asp - Ser - Gly - Leu - Cys (S - bridged) - Met - Pro - Arg - Leu Arg - Gly - Cys (S - bridged) - Asp - Pro - Arg - $\mathrm{NH}_{2}$ ] (Marcor 2009). This lead compound led to the design of a new peptide-based vector: VH0445 (Ac - [cMet - Pro - Arg - Leu Arg - Gly - Cys]c - $\mathrm{NH}_{2}$ ), a cyclic 8 amino acid peptide containing natural and non-natural amino acids (Malcor, Payrot et al. 2012). In vivo preclinical proof of principal data has been established in an acute pain mouse model by conjugation of $\mathrm{VH} 0445$ to an opioid peptide and an assessment of antinociceptive activity; a sharp improvement in antinociceptive activity was observed (Vlieghe and Khrestchatisky 2010; Vlieghe, Lisowski et al. 2010; Malcor, Payrot et al. 2012).

\subsubsection{Transferrin receptor}

ArmaGen Technologies have developed brain delivery technology (fusion proteins) based on genetic engineering of recombinant fusion proteins wherein the bioactive protein is fused to a molecular "Trojan horse" transporter protein. Fusion proteins have dual functions as they cross the BBB via one of the endogenous BBB receptor-mediated transport systems (e.g. the transferrin receptor) and bind neuronal or glial receptors in the brain parenchyma (Pardridge and Boado 2007; Pardridge and Boado 2008; Pardridge and Boado 2009; Pardridge and Boado 2010).

OX26, a rat transferrin receptor monoclonal antibody, has been used to successfully target polymersomes and nanoparticles across the BBB. The optimal number of OX26 molecules conjugated to poly(ethylene glycol) - poly(epsilon - caprolactone) (PEG - PCL) polymersomes was found to be $34\left(\mathrm{OX} 26_{34}-\mathrm{PO}\right)$ and this system resulted in the delivery of $0.14-0.16 \%$ of the intravenously injected dose to the brain (Pang, Lu et al. 2008). NC-1900 (a vasopressin fragment with neuroprotective properties) was encapsulated into OX26 ${ }_{34}$ - PO and the NC -1900 - OX26 $6_{34}$ - PO system improved the scopolamine-induced learning and 
reduced memory impairment in a rat water maze task after intravenous administration (Pang, Lu et al. 2008). Conjugation of OX26 to poly(ethylene glycol) chitosan nanoparticles also resulted in enhanced brain uptake after intravenous administration of an anticaspase peptide, Z-DEVD-FMK (Aktas, Yemisci et al. 2005).

A peptide motif obtained from phage display experiments and with a high affinity for transferrin receptors (CGHKAKGPRK, denoted as B6) has also shown potential in enabling the permeation of poly(ethylene glycol) - poly(lactic acid) block copolymer (PEG - PLA) nanoparticles to the brain (Liu, Gao et al. 2013). B6 nanoparticles exhibited significantly enhanced cellular accumulation compared to plain PEG - PLA nanoparticles and cellular uptake was achieved via lipid raft-mediated and clathrin - mediated endocytosis. B6 PEG PLA nanoparticles were loaded with an octapeptide (NAPVSIPQ) derived from an activity dependent neuroprotective protein and which is being trialled clinically in Alzheimer's Disease patients (Gozes, Divinski et al. 2008). Administration of B6 nanoparticles encapsulating the neuroprotective peptide NAPVSIPQ to Alzheimer's disease mouse models resulted in excellent amelioration of learning impairments, cholinergic disruption, and a reduced loss of hippocampal neurons (Liu, Gao et al. 2013).

A comparative study of nanoparticles bearing targeting ligands and their brain delivery data has been conducted with intravenously injected tritiated liposomes (van Rooy, Mastrobattista et al. 2011). Five targeting ligands were compared, namely: a) holotransferrin (a transmembrane glycoprotein, consisting of two linked $90 \mathrm{kDa}$ subunits, that each can bind a transferrin molecule) (Mishra, Mahor et al. 2006; Ulbrich, Hekmatara et al. 2009), b) RI7217, an anti-mouse transferrin receptor monoclonal antibody (Ulbrich, Hekmatara et al. 2009), c) COG133, an apolipoprotein E mimetic peptide from amino acids 133 - 149 (LRVRLASHLRKLRKRLL), e) Angiopep - 2 (Li, Sempowski et al. 2006) and f) CRM 197 (a non-toxic mutant of the diphtheria toxin) (Gaillard, Brink et al. 2005; Gaillard and de Boer 
2006). Almost half of the injected dose of all the liposomes was recovered in the liver and spleen 12h after dosing (van Rooy, Mastrobattista et al. 2011). The COG133 peptide was unable to target the liposomes to the BBB. Only the anti-mouse transferrin antibody, RI7217, was able to improve the delivery of the liposomes to the brain. van Rooy's data is interesting as in vivo brain targeting of albumin nanoparticle conjugated RI7217 had been demonstrated previously (Ulbrich, Hekmatara et al. 2009), but van Rooy's study was the first report to demonstrate brain delivery with liposome conjugated $\mathrm{RI} 7217$ to the brain $(0.18 \%$ of the injected dose was found in the brain $12 \mathrm{~h}$ after dosing) (van Rooy, Mastrobattista et al. 2011).

\subsubsection{Leptin receptor}

Leptin, a $16 \mathrm{kDa}$ protein produced in white peripheral adipocytes, binds to the leptin receptor in the choroid plexus and on the brain capillary endothelial cells, where it is taken up into the brain parenchyma (Banks 2001). The leptin receptor may be saturated in obese patients that have elevated levels of leptin (Kd of the receptor is similar to normal serum levels) (Burgueraa and Couceb 2001). A leptin ${ }_{12-32}$ fragment, g21, conjugated on the surface of poly(lactic - co - glycolic) acid (PLGA) nanoparticles has been shown to cross the BBB on intravenous injection, with $0.16 \%$ of the injected dose of nanoparticles reaching the brain after $2 \mathrm{~h}$ (Tosi, Badiali et al. 2012). No anorectic effects were seen in rats after the intravenous administration of $0.03 \mu \mathrm{g}$ of the g21 transport ligand conjugated to nanoparticles (Tosi, Badiali et al. 2012).

\subsection{Cell Penetrating Peptides}

Cell-Penetrating Peptides (CPPs) originate from various families and are heterogeneous in size (10 - 27 amino acid residues) and sequence, but they all possess multiple positive charges at physiological $\mathrm{pH}$. Some of them share common features such as an amphipathic sequence and the ability to interact with a lipid membrane (Morris, Deshayes et al. 2008; 
Eiriksdottira, Konateb et al. 2010). Examples include the transcription-activating factor (TAT), penetratin and the SynB vectors (family of vectors derived from the antimicrobial peptide protegrin 1). A number of other CPPs are the product of engineering efforts, e.g. the homoarginine vectors, the model amphipathic peptide, transportan and other chimeric peptides such as signal-based peptide (SBP) and the fusion sequence-based peptide (FBP) (Herve, Ghinea et al. 2008).

The TAT peptide is a non-amphipathic arginine-rich CPP derived from the TAT protein originating from the human immunodeficiency virus type 1 (HIV - 1), a multifunctional viral protein named originally for its intracellular role as a transcriptional activator of viral gene expression (Subrizi, Tuominenb et al. 2013). The TAT protein is actively released from unruptured, HIV - 1 infected cells and is detectable in ex vivo culture supernatants and in the serum of HIV - 1 infected individuals (Subrizi, Tuominenb et al. 2013). This exogenous TAT is able to enter both uninfected and infected cells, however the precise molecular mechanism by which TAT enters the cells is still unclear. TAT binds to cell-surface heparin sulphate and the binding of the full - length TAT protein to both heparin sulphate proteoglycans and the low - density lipoprotein receptor family has been confirmed (Rusnati, Coltrini et al. 1997; Liu, Jones et al. 2000). The basic domain of TAT extending from residues 49 to 58 (RKKRRQRRR) includes a highly cationic cluster composed of 6 arginine and 2 lysine residues that play an important role in the translocation of the protein across biological membranes; translocation is aided by the strong cell adherence of this motif and cell binding is independent of cell receptors and of temperature (Subrizi, Tuominenb et al. 2013). The guanidinium head group of arginine is required for peptide uptake and is more potent than other cationic groups, such as lysine, histidine or ornithine (Mitchell, Steinman et al. 2000). The mechanism of cellular penetration, which is often compared to a Trojan horse approach, involves two distinct steps: endocytic uptake followed by endosomal escape (Erazo-Oliveras, Muthukrishnan et al. 2012). 
Memapsin - 2 ( $\beta$-secretase or BACE) inhibitors are particularly attractive candidates for Amyloid $\beta$ reduction therapy since $\beta$ - secretase cleavage of amyloid precursor protein represents the initial step in the biogenesis of Amyloid $\beta$. It is hypothesised that the inhibition of this step would lead to the elimination of all steps in the pathogenesis of Alzheimer's disease, but memapsin - 2 inhibitors are not able to permeate the BBB. Conjugation of a 12 residue TAT fragment but preferably a 9-residue poly - D - Arginine to a peptide analogue inhibitor of memapsin (Wender, Mitchell et al. 2000) resulted in a 64\% reduction of Amyloid $\beta$ levels after a single intraperitoneal injection (Chang, Koelsch et al. 2004). Multiple injections to simulate a longer half life of the inhibitor produced maximal inhibition of about $90 \%$ in the plasma and about $70 \%$ in the brain (Chang, Koelsch et al. 2004).

Nanoparticulate drug delivery system possesses distinct advantages for brain drug delivery. However, their permeation across the BBB is not always therapeutically adequate. Cellpenetrating peptides (CPPs), short peptides that facilitate cellular uptake of various molecular cargoes, would be appropriate candidates for facilitating brain delivery of nanoparticles encapsulating peptides. Examples of the use of CPPs to deliver nanoparticles across the BBB are given below

The SynB peptides (RGGRLSYSRRRFSTSTGR) are a family of cell-penetrating peptides that show charge - mediated BBB selectivity, with uptake proceeding via a caveolaeindependent pathway (Drin, Cottin et al. 2003). The SynB peptide family is derived from the natural antimicrobial peptide protegrin 1 (PG - 1) originally isolated from porcine leukocytes. PG -1 is an 18 amino acid long peptide with an antiparallel beta-sheet structure stabilized by two disulfide bridges. It interacts with, and forms pores in the lipid matrix of bacterial membranes. Various linear analogues of $P G-1$ that lack cysteine residues have been designed and these are devoid of the membrane-disrupting activity of PG -1 (Harwig, Waring et al. 1996; Mangoni, Aumelas et al. 1996; Chen, Falla et al. 2000). 
SynB peptides have been used extensively as cationic cell penetrating peptides for low molecular weight actives (Adenot, Merida et al. 2007) and for peptides such as dalargin (Rousselle, Clair et al. 2003); with transport observed across cell membranes in vitro and across the BBB in vivo when administered intravenously. There have also been recent reports of the use of SynB peptides as brain transport systems for nanoparticles. For example, intravenously injected SynB pegylated gelatin siloxane nanoparticle (SynB - PEG GS) levels in the brain were significantly higher and levels in the liver significantly lower compared to plain nanoparticles (Tian, Wei et al. 2012).

Penetratin, a CPP with a relatively low content of basic amino acids, has been used to functionalize poly(ethylene glycol)-block-poly(lactic acid) (PEG - PLA) nanoparticles and penetratin enhanced the cellular accumulation (Xia, Gao et al. 2012). In vivo pharmacokinetic and biodistribution studies showed that penetratin nanoparticles exhibited significantly enhanced brain uptake and reduced accumulation in the non-target tissues compared with low molecular weight protamine (a CPP with high arginine content) functionalized nanoparticles (Xia, Gao et al. 2012).

A thermally responsive elastin like polypeptide (ELP) covalently attached to a cellpenetrating peptide and a therapeutic inhibitory peptide (inhibits the oncogenic c - Myc protein) has been shown to be able to enhance delivery to rat brain tumours and mediate uptake across the tumour cells' plasma membranes on intravenous administration (Table 1) (Bidwell, Perkins et al. 2013). Specifically, when the lead CPP - ELP - fused c - Myc inhibitor was combined with focused hyperthermia of the tumours, an 8 fold increase in tumour polypeptide levels was observed. Additionally an $80 \%$ reduction in tumour volume was recorded along with a delayed onset of tumour-associated neurological deficits, a doubling of the median survival time and complete tumour regression in $80 \%$ of the animals (Bidwell, Perkins et al. 2013). 
The ability of CPPs to penetrate many cell types in vitro, as well as in vivo greatly restricts their application as pharmaceutical tools and hence methods of targeting CPPs are being investigated. Such strategies may exploit specific cell features, such as extracellular receptors or enzymes, or use of small or large cell-binding ligands (e.g. vitamins, growth factors or antibodies) which, when incorporated into CPPs, may render these cationic peptides capable of distinguishing between non-target and target cells (Herve, Ghinea et al. 2008). The stability of peptide vectors is an important factor regarding their use for in vivo delivery, as the vector must not be metabolically cleaved until it delivers its cargo to the appropriate target. In studies, transportan (GWTLNSAGYLLGKINLKALAALAKKIL amide), its analogue transportan 10 (TP10, AGYLLGKINLKALAALAKKIL amide) and TAT (47-57) (YGRKKRRQRRR) were shown to be more stable than penetratin (RQIKIWFQNRRMKWKK) for example (Herve, Ghinea et al. 2008). The use of D-amino acids is one way to enhance the stability of these transport peptides. However, it is critical that when the vector reaches its target it should subsequently degrade or release its cargo in order to elicit its pharmacological response. Toxicity and immunogenicity are also important issues to be considered when translating these brain delivery strategies to the clinic. The full - length TAT protein produced lower levels of neurotoxicity than the shorter peptides TAT (31 - 71) and TAT (31 - 61) in that order (Herve, Ghinea et al. 2008). Both the cysteine - rich domain extending from residues 32 to 47 and the basic domain (positions $48-57$ ) seem to be essential for neurotoxicity to develop (Herve, Ghinea et al. 2008). The assessment of the toxicity of unmodified CPPs using a lactate dehydrogenase (LDH)-leakage, DiBAC4(3) (membrane depolarization), and hemolytic assay showed rather severe toxic effects of transportan 10 as representative of the amphipathic CPPs, but it showed only mild effects of the arginine - rich peptides TAT and penetratin (Tünnemann and Cardoso 2009). However, the toxicological properties can be dramatically changed on attachment of low-molecularweight cargoes, for example, labels or other peptides (Tünnemann and Cardoso 2009). 
Finally, as CPPs are derived from non-human proteins and since, in the case of administration to humans, these peptides have the potential to induce an immune response; one must consider that this risk of an immune response may increase considerably if these vectors are conjugated to particularly large peptide molecules.

\subsection{Passive Delivery}

\subsubsection{Polymeric Nanoparticles:}

Peptide brain delivery may also be achieved by using a polymeric or lipid nanocarrier loaded with a hydrophilic peptide. Various examples of such strategies have been reported and the majority of these approaches are exemplified with analgesic peptides (Table 2) (Aliautdin, Petrov et al. 1996; Lalatsa, Garrett et al. 2012; Lalatsa, Lee et al. 2012). Nanomerics Ltd (St Albans, U. K.), for example, is exploiting technology based on an engineered amphiphilic chitosan polymer (Quaternary ammonium palmitoyl glycol chitosan - GCPQ) tailored to form nanoscale polymeric aggregates that are able to package or specifically interact with peptides. Preclinically the technology has been successful in delivering leucine ${ }^{5}$ - enkephalin (an endogenous opioid peptide with a plasma half-life of 3 minutes) across the BBB, with anti-nociceptive activity demonstrated in a rodent acute pain animal model after both intravenous (Lalatsa, Garrett et al. 2012) and oral administration (Lalatsa, Garrett et al. 2012) (Table 2). The anti - nociceptive response in these studies lasted for up to 8 hours. The ability to elicit a short lived pharmacological effect (30 minutes and 90 minutes) after the administration of dalargin (a mu opioid receptor agonist peptide) loaded poly(butyl cyanoacrylate) nanoparticles coated with either polysorbate 80 or poly(ethylene glycol) (molecular weight $=20 \mathrm{kDa}$ ) via the intravenous and oral route respectively has also been shown (Schroeder, Sommerfeld et al. 1998; Das and Lin 2005). A polysorbate 80 coating of the poly(butyl cyanoacrylate) nanoparticles was critical for dalargin entry into the brain as this coating enables the particles to adsorb Apolipoprotein $E$ from the blood plasma onto the 
nanoparticle surface and it is this Apolipoprotein E coating that is believed to facilitate transport across the BBB via the LDL - receptor (Kreuter, Shamenkov et al. 2002).

Vesicles prepared from bolaamphiphiles containing two hydrophilic head groups at each end of a hydrophobic lipidic chain have been used to enhance permeation of small hydrophilic analgesic peptides across the BBB and are characterised by high chemical and physical stability and the ability to be destabilised by esterases leading to changes in the head groups; such head group changes disrupt the vesicular structure and release the encapsulated peptide in tissues with high acetylcholinesterase activity such as the brain (Popov, Abu Hammad et al. 2013). The presence of chitosan pendant groups appears to enhance antinociception elicited with these bolaamphiphilic vesicles (Table 2). 
Table 2: Peptide delivery across the BBB

\begin{tabular}{|c|c|c|c|c|}
\hline Strategy & Peptide & $\begin{array}{l}\text { Develop- } \\
\text { mental Stage } \\
\text { - Route }\end{array}$ & Therapeutic advantage & References \\
\hline \multicolumn{5}{|l|}{ Passive Delivery } \\
\hline \multicolumn{5}{|c|}{ Polymeric Nanoparticles } \\
\hline $\begin{array}{l}\text { Quaternary } \\
\text { ammonium } \\
\text { palmitoyl glycol } \\
\text { chitosan (GCPQ) } \\
\text { nanoparticles }\end{array}$ & $\begin{array}{l}\text { Leucine }^{5} \text { - } \\
\text { enkephalin, } \\
\text { Tyrosyl }^{1} \\
\text { Palmitate- } \\
\text { Leucine }^{5} \text { - } \\
\text { enkephalin } \\
\text { (Lipidised } \\
\text { prodrug of } \\
\text { Leucine }{ }^{5} \text { - } \\
\text { enkephalin) }\end{array}$ & $\begin{array}{l}\text { Preclinical - } \\
\text { Intravenous, } \\
\text { Oral }\end{array}$ & $\begin{array}{l}\text { A sustained anti- } \\
\text { nociceptive effect on } \\
\text { intravenous and oral } \\
\text { administration and } \\
\text { enhanced levels of } \\
\text { leucine }{ }^{5} \text { - enkephalin are } \\
\text { detected in the brain. } \\
\text { Leucine }^{5} \text { - enkephalin } \\
\text { alone is inactive. }\end{array}$ & $\begin{array}{l}\text { (Lalatsa, } \\
\text { Garrett et al. } \\
2012 ; \\
\text { Lalatsa, } \\
\text { Garrett et al. } \\
2012)\end{array}$ \\
\hline $\begin{array}{l}\text { Poly(butyl } \\
\text { cyanoacrylate ) } \\
\text { nanoparticles } \\
\text { coated with } \\
\text { polysorbate - } 80\end{array}$ & Dalargin & $\begin{array}{l}\text { Preclinical - } \\
\text { Intravenous }\end{array}$ & Enhanced antinociception. & $\begin{array}{l}\text { (Schroeder, } \\
\text { Sommerfeld } \\
\text { et al. 1998) }\end{array}$ \\
\hline \multicolumn{5}{|l|}{ Bolaamphiphiles } \\
\hline $\begin{array}{l}\text { Bolaamphiphile } \\
\text { vesicles }\end{array}$ & $\begin{array}{l}\text { Leucine }^{5} \text { - } \\
\text { enkephalin }\end{array}$ & $\begin{array}{l}\text { Preclinical - } \\
\text { Intravenous }\end{array}$ & $\begin{array}{l}\text { Vesicles produced using } \\
\text { GLH -19 and GLH - } 20\end{array}$ & $\begin{array}{l}\text { (Popov, Abu } \\
\text { Hammad et }\end{array}$ \\
\hline
\end{tabular}




\begin{tabular}{|c|c|c|c|c|}
\hline Strategy & Peptide & $\begin{array}{l}\text { Develop- } \\
\text { mental Stage } \\
\text { - Route }\end{array}$ & Therapeutic advantage & References \\
\hline $\begin{array}{l}\text { (prepared from } \\
\text { GLH - 19, GLH - } \\
20, \text { or a mixture of } \\
\text { GLH - } 19 \text { and GLH } \\
\text { - 20, with and } \\
\text { without chitosan } \\
\text { pendant groups) }\end{array}$ & & & $\begin{array}{l}\text { bolalipids loaded leucine }^{5} \text { - } \\
\text { enkephalin produced } \\
\text { enhanced antinociceptive } \\
\text { effects upon intravenous } \\
\text { administration, particularly } \\
\text { when the bolaamphiphiles } \\
\text { loaded with leucine }{ }^{5} \text { - } \\
\text { enkephalin contained } \\
\text { chitosan pendant groups. }\end{array}$ & al. 2013) \\
\hline \multicolumn{5}{|c|}{ Peptide Amphiphiles } \\
\hline Nanofibers & $\begin{array}{l}\text { O - palmitoyl } \\
\text { tyrosinate } \\
\text { ester }{ }^{1} \text {-dalargin }\end{array}$ & $\begin{array}{l}\text { Preclinical - } \\
\text { Intravenous }\end{array}$ & $\begin{array}{l}\text { Prolonged antinociceptive } \\
\text { response. Dalargin alone } \\
\text { is inactive. }\end{array}$ & $\begin{array}{l}\text { (Mazza, } \\
\text { Notman et al. } \\
\text { 2013) }\end{array}$ \\
\hline $\begin{array}{l}\text { Amphiphilic } \\
\text { peptide core - } \\
\text { shell } \\
\text { nanoparticles }\end{array}$ & $\begin{array}{l}\text { Amphiphilic } \\
\text { peptide } \\
\text { (CGGGRRRRR } \\
\text { RTAT) }\end{array}$ & $\begin{array}{l}\text { Preclinical - } \\
\text { Intravenous }\end{array}$ & $\begin{array}{l}\text { Enhanced antimicrobial } \\
\text { activity in a } \\
\text { Staphylococcus aureus in } \\
\text { vivo meningitis model in } \\
\text { rabbits (two intravenous } \\
\text { doses) }\end{array}$ & $\begin{array}{l}\text { (Liu, Xu et al. } \\
\text { 2009) }\end{array}$ \\
\hline \multicolumn{5}{|c|}{ Actively targeted nanoparticles } \\
\hline $\begin{array}{l}\text { Glutathione } \\
\text { Poly(ethylene }\end{array}$ & $\begin{array}{l}\text { DAMGO (H-Tyr } \\
\text { - d - Ala - Gly - }\end{array}$ & $\begin{array}{l}\text { Preclinical - } \\
\text { Intravenous }\end{array}$ & $\begin{array}{l}\text { Enhancement of plasma } \\
\text { half life and doubling of }\end{array}$ & $\begin{array}{l}\text { (Lindqvist, } \\
\text { Rip et al. }\end{array}$ \\
\hline
\end{tabular}




\begin{tabular}{|c|c|c|c|c|}
\hline Strategy & Peptide & $\begin{array}{l}\text { Develop- } \\
\text { mental Stage } \\
\text { - Route }\end{array}$ & Therapeutic advantage & References \\
\hline $\begin{array}{l}\text { glycol) liposomes } \\
\text { (GSH - PEG } \\
\text { liposomes) }\end{array}$ & $\begin{array}{l}\text { MePhe - Gly - } \\
\text { ol) }\end{array}$ & & $\begin{array}{l}\text { brain exposure of DAMGO } \\
\text { when administered as a } \\
\text { GSH - PEG liposomal } \\
\text { formulation }\end{array}$ & 2013) \\
\hline $\begin{array}{l}\text { OX26 - } \\
\text { poly(ethylene } \\
\text { glycol) - block - } \\
\text { poly (epsilon } \\
\text { caprolactone) } \\
\text { (PEG - PCL) } \\
\text { polymersomes }\end{array}$ & $\begin{array}{l}\text { NC1900 (a } \\
\text { vasopressin } \\
\text { fragment) }\end{array}$ & $\begin{array}{l}\text { Preclinical - } \\
\text { Intravenous }\end{array}$ & $\begin{array}{l}\text { Improved the scopolamine } \\
\text { - induced learning and } \\
\text { memory impairments in a } \\
\text { water maze task after } \\
\text { intravenous administration } \\
\text { in rats }\end{array}$ & $\begin{array}{l}\text { (Pang, Lu et } \\
\text { al. 2008) }\end{array}$ \\
\hline $\begin{array}{l}\text { OX26 } \\
\text { poly(ethylene } \\
\text { glycol) chitosan } \\
\text { nanoparticles }\end{array}$ & $\begin{array}{l}\text { Z-DEVD-FMK (a } \\
\text { specific caspase } \\
\text { inhibitor) }\end{array}$ & $\begin{array}{l}\text { Preclinical - } \\
\text { Intravenous }\end{array}$ & $\begin{array}{l}\text { Enhanced brain } \\
\text { translocation after } \\
\text { intravenous administration } \\
\text { in Swiss albino mice }\end{array}$ & $\begin{array}{l}\text { (Aktas, } \\
\text { Yemisci et al. } \\
\text { 2005) }\end{array}$ \\
\hline $\begin{array}{l}\text { Lactoferrin PEG - } \\
\text { PCL } \\
\text { nanoparticles }\end{array}$ & NAPVSIPQ & $\begin{array}{l}\text { Preclinical - } \\
\text { Intranasal }\end{array}$ & $\begin{array}{l}\text { Administration lactoferrin } \\
\text { PEG - PCL nanoparticles } \\
\text { loaded with NAPVSIPQ } \\
\text { improved behaviour in a } \\
\text { Morris water maze } \\
\text { experiment when } \\
\text { compared to NAPVSIPQ } \\
\text { PEG - PCL nanoparticles }\end{array}$ & $\begin{array}{l}\text { (Liu, Jiang et } \\
\text { al. 2013) }\end{array}$ \\
\hline
\end{tabular}




\begin{tabular}{|c|c|c|c|c|}
\hline Strategy & Peptide & $\begin{array}{l}\text { Develop- } \\
\text { mental Stage } \\
\text { - Route }\end{array}$ & Therapeutic advantage & References \\
\hline & & & alone. & \\
\hline $\begin{array}{l}\text { Angiopep - } 2 \\
\text { Neurotensin } \\
\text { (ANG2002) }\end{array}$ & Neurotensin & $\begin{array}{l}\text { Preclinical - } \\
\text { Intravenous }\end{array}$ & $\begin{array}{l}\text { Enhancement of the foot } \\
\text { licking latency in a mouse } \\
\text { hot plate assay, reduced } \\
\text { licking responses in } \\
\text { formalin - induced pain } \\
\text { model and reduced } \\
\text { mechanical allodynia in } \\
\text { both a Brennan post- } \\
\text { operative pain model and } \\
\text { a Chung model for } \\
\text { neuropathic pain }\end{array}$ & $\begin{array}{l}\text { (Demeule, } \\
\text { Regina et al. } \\
\text { 2010) }\end{array}$ \\
\hline $\begin{array}{l}\text { VH0445 peptide } \\
\text { conjugates }\end{array}$ & Opioid peptide & $\begin{array}{l}\text { Preclinical - } \\
\text { Intravenous }\end{array}$ & $\begin{array}{l}\text { Enhancement of } \\
\text { antinociceptive activity in } \\
\text { mice }\end{array}$ & $\begin{array}{l}\text { (Vlieghe and } \\
\text { Khrestchatis } \\
\text { ky 2010; } \\
\text { Vlieghe, } \\
\text { Lisowski et } \\
\text { al. 2010; } \\
\text { Malcor, } \\
\text { Payrot et al. } \\
\text { 2012) }\end{array}$ \\
\hline \multicolumn{5}{|c|}{ Cell Penetrating Peptide Conjugates } \\
\hline Cell penetrating & c- Myc & Preclinical - & Combining CPP - ELP & (Bidwell, \\
\hline
\end{tabular}




\begin{tabular}{|c|c|c|c|c|}
\hline Strategy & Peptide & $\begin{array}{l}\text { Develop- } \\
\text { mental Stage } \\
\text { - Route }\end{array}$ & Therapeutic advantage & References \\
\hline $\begin{array}{l}\text { peptide - elastin } \\
\text { like polypeptide } \\
\text { fused to c - Myc } \\
\text { inhibitory peptide }\end{array}$ & $\begin{array}{l}\text { inhibitory } \\
\text { peptide }\end{array}$ & Intravenous & $\begin{array}{l}\text { fused c - Myc inhibitor with } \\
\text { focused hyperthermia of } \\
\text { the tumours, resulted in an } \\
80 \% \text { reduction in tumour } \\
\text { volume, delayed onset of } \\
\text { tumour-associated } \\
\text { neurological deficits, and a } \\
\text { doubling of the median } \\
\text { survival time. There was } \\
\text { also complete tumour } \\
\text { regression in } 80 \% \text { of } \\
\text { animals. }\end{array}$ & $\begin{array}{l}\text { Perkins et al. } \\
\text { 2013) }\end{array}$ \\
\hline TAT- NBD peptide & $\begin{array}{l}\text { NBD (anti - NF- } \\
\text { KB peptide) }\end{array}$ & $\begin{array}{l}\text { Preclinical - } \\
\text { Intanasal }\end{array}$ & $\begin{array}{l}\text { Delivery of } 1.4 \mathrm{mg} \mathrm{kg}^{-1} \\
\text { TAT - NBD, markedly } \\
\text { attenuates NF-KB } \\
\text { signalling, microglia } \\
\text { activation, and brain } \\
\text { damage triggered by } \\
\text { hypoxic ischemia }\end{array}$ & $\begin{array}{l}\text { (Yang, Sun } \\
\text { et al. 2013) }\end{array}$ \\
\hline
\end{tabular}




\begin{tabular}{|c|c|c|c|c|}
\hline Strategy & Peptide & $\begin{array}{l}\text { Develop- } \\
\text { mental Stage } \\
\text { - Route }\end{array}$ & Therapeutic advantage & References \\
\hline $\begin{array}{l}9 \text { - residue poly - } \\
\text { D - Arginine - } \\
\text { Memapsin - } 2\end{array}$ & $\begin{array}{l}\text { Memapsin - } 2(\beta \\
\text { - secretase } \\
\text { inhibitor })\end{array}$ & $\begin{array}{l}\text { Preclinical - } \\
\text { Intraperitoneal }\end{array}$ & $\begin{array}{l}\text { Multiple injections } \\
\text { produced a maximal } \\
\text { reduction in Amyloid } \beta \\
\text { levels (a reduction of } 90 \% \\
\text { in the plasma and } 70 \% \text { in } \\
\text { the brain) in transgenic } \\
\text { Tg2576 mice }\end{array}$ & $\begin{array}{l}\text { (Chang, } \\
\text { Koelsch et } \\
\text { al. 2004) }\end{array}$ \\
\hline SynB - Dalargin & Dalargin & $\begin{array}{l}\text { Preclinical - } \\
\text { Intravenous }\end{array}$ & $\begin{array}{l}\text { Enhancement of } \\
\text { antinociception of Dalargin } \\
\text { in a hot-plate murine } \\
\text { model }\end{array}$ & $\begin{array}{l}\text { (Rousselle, } \\
\text { Clair et al. } \\
\text { 2003) }\end{array}$ \\
\hline \multicolumn{5}{|c|}{$\begin{array}{l}\text { Key; c-Myc: oncogenic protein expressed in } 78 \% \text { of human glioblastoma multiforme tumours, GLH } \\
\text { 19: Acetyl choline head groups attached via the oxygen atoms to vernonia oil derivatives, GLH-20 } \\
\text { Acetyl choline head groups attached via the nitrogen atoms to vernonia oil derivatives, NAPVSIPQ } \\
\text { Asparagine-Alanine-Proline-Valine-Serine-Isoleucine-Proline-Glutamine, NC 1900: Vasopressin } \\
\text { fragment, NGF: Nerve growth factor, OX26: anti-transferrin receptor antibody IgG2a, TAT peptide } \\
\text { Tyrsoine-Glycine-Arginine-Lysine-Lysine-Lysine-Arginine-Arginine-Glutamine-Arginine-Arginine- } \\
\text { Arginine, TAT-NBD: } 22 \text { amino-acid CPP containing the NF - KB Essential Modulator (NEMO)/IKKY } \\
\text { Binding Domain coupled to the transduction sequence of the HIV - TAT protein, VH0445: Ac-[CMet } \\
\text { Pro-Arg-Leu-Arg-Gly-Cys]c-NH2), a cyclic 8-mer peptide with enhanced permeation across the blood- } \\
\text { spinal cord barrier. }\end{array}$} \\
\hline
\end{tabular}

\subsubsection{Peptide amphiphiles}

Peptides can molecularly arrange into a variety of structures mediated by hydrogen bonding, electrostatic interactions particularly between charged amino acids, hydrophobic associations and $\pi-\pi$ stacking (Ulijn and Smith 2008). Amphipathic peptides possess both hydrophobic and hydrophilic parts and they can be natural peptides (as with penetratin for example), engineered by inclusion of hydrophobic and hydrophilic amino acid mini blocks or 
by point lipidisation of specific amino acid residues, e.g. by conjugation for example of a hydrophobic alkyl or acyl chain. The distinct separation between the hydrophilic and hydrophobic parts of the molecule drives self-assembly in aqueous environments and the net result is the formation of spherical (Zhang, Marini et al. 2002), membrane (Zhang, Holmes et al. 1993), hydrogel (Zhang, Marini et al. 2002) or fibrous aggregates (Zhang, Marini et al. 2002; Mazza, Notman et al. 2013). Peptide micellar aggregates and nanofibres have been successfully used to deliver peptides across the BBB.

Peptide nanofibres are typically prepared by probe sonication of an aqueous dispersion of the peptide amphiphile. Peptide nanofibres consist of a central hydrophobic core surrounded by a $\beta$ - sheet of peptides (Paramonov, Jun et al. 2006) with the peptide $\beta$ - sheet wrapped tightly around the hydrocarbon core (Mazza, Notman et al. 2013) and the cylindrical assembly primarily driven by the $\beta$ - sheet. The presence of a $\beta$ - sheet forming peptide sequence, a charged amino acid and an alkyl chain linked to one end of the peptide have been proposed as critical parameters important for engineering peptide nanofibres (Cui, Webber et al. 2010). Our group was the first to show that therapeutic peptides could be made to assemble into peptide nanofibres, with the report that the acyl derivatised therapeutic peptide, namely $O$ - palmitoyl tyrosinate ester ${ }^{1}$ - dalargin self assembles into nanofibres (Mazza, Notman et al. 2013). These nanofibres cross the BBB and produce a pharmacological response on intravenous administration; whereas the peptide dalargin alone is inactive via this route (Mazza, Notman et al. 2013). Furthermore peptide nanofibres in which the peptide does not contain a charged amino acid have been produced from Opalmitoyl tyrosinate ester ${ }^{1}$ - leucine ${ }^{5}$ - enkephalin and this molecule also is active via the intravenous route, where again the peptide alone is inactive. These peptide nanofibres act as a self assembled prodrug, releasing the drug itself from its ester linkage in vivo ((Lalatsa, Schatzlein et al. 2013; Mazza, Notman et al. 2013). A passive mechanism of transport for the peptide nanofibers is envisaged due to the increased lipophilicity of the peptide 
amphiphiles, but the mechanism of transport has not yet been fully elucidated. Peptide nanofibres are a promising delivery strategy for the transport of peptides across the BBB.

Amphiphilic engineered peptides (CGGGRRRRRRTAT) able to form core-shell nanoparticles also demonstrate enhanced antimicrobial activity in a Staphylococcus aureus in vivo meningitis model. Peptide amphiphile spherical aggregates have been prepared by incubation of the peptide amphiphile in aqueous media at $35^{\circ} \mathrm{C}$ for 24 hours (Liu, Xu et al. 2009).

\subsection{Oral Administration}

Technologies able to ensure non-invasive delivery of peptide and protein therapies to the brain hold immense commercial potential. The oral and the intranasal route are the only routes that have shown some promise in this respect. The low bioavailability of peptides via the oral route which is a direct result of their physical and enzymatic instability and their low permeability across biological membranes may be overcome by the use of nanoparticle technologies (Serrano Lopez and Lalatsa 2013). The pharmaceutical industry, driven by the medical and clinical success of intravenously administered biologics is increasingly investigating more complex brain peptide delivery systems in order to enter niche treatment markets and address the growing need for brain therapeutics. An oral to brain peptide delivery technology may provide an answer to a therapeutic field with unmet needs in the form of drugs to treat an ever growing catalogue of neurological diseases (neurodegeneration, pain and cancer for example).

Nanoparticle technologies are the only strategies able to protect peptides in the harsh environment of the gastrointestinal tract, enhance their absorption across the gastrointestinal mucosa and increase their circulation half life in order to maintain an adequate concentration of peptide in the plasma for transport across the BBB. Oral to brain peptide delivery, has been demonstrated with opioid peptide analgesics. The first reported strategy able to deliver 
peptides orally involved the analgesic peptide dalargin, encapsulated in poly(butylcyanoacrylate) nanoparticles coated with either polysorbate 80 (Schroeder, Sommerfeld et al. 1998) or polyethylene glycol (molecular weight $=20 \mathrm{kDa}$ ) (Das and Lin 2005). However, although the intellectual property protection was secured for this technology over 15 years ago (Sabel B. A. and U. 1997), the technology appears not to have progressed beyond the preclinical stage.

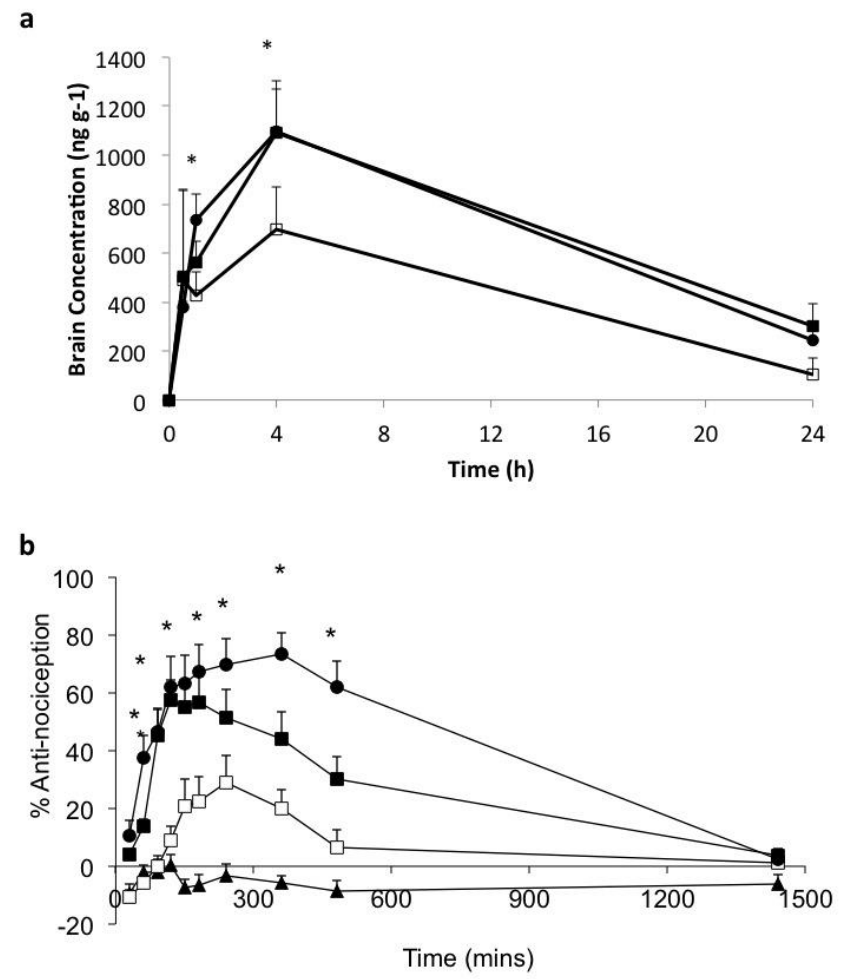

Figure 2a: Brain levels showing the oral to brain delivery of leucine ${ }^{5}$-enkephalin $\left(70 \mathrm{mg} \mathrm{kg}^{-1}, \mathbf{\square}\right)$ and a lipidised leucine ${ }^{5}$-enkephalin prodrug (O-tyrosinyl palmitate leucine ${ }^{5}$-enkephalin, $100 \mathrm{mg} \mathrm{kg}^{-1}$, encapsulated in Nanomerics Molecular Envelope Technology (GCPQ Nanoparticles). Brain levels of leucine ${ }^{5}$-enkephalin alone $(\square)$ are also shown. Figure 2b: The anti-nociceptive response following the oral administration of leucine ${ }^{5}$-enkephalin and O-tyrosinyl palmitate leucine ${ }^{5}$-enkephalin encapsulated in Nanomerics Molecular Envelope Technology. Symbols are as in Figure 2a. A group of mice were also dosed with water $(\boldsymbol{\Delta})$. The drug, GCPQ ratio was 1: $5 \mathrm{~g} \mathrm{~g} \mathrm{~g}^{-1}$. Reproduced with permission from reference (Lalatsa, Lee et al. 2012).
Nanomerics Ltd (St Albans, U. K.) has shown that its proprietary Molecular Envelope Technology (MET) - quaternary ammonium palmitoyl glycol chitosan (GCPQ) nanoparticles achieves the oral delivery of peptides and lipophilic peptide prodrugs to the brain (Lalatsa, Garrett et al. 2012; Lalatsa, Lee et al. 2012). The technology works by protecting the peptide from degradation in the gut, the nanoparticles being taken up by the enterocytes, the absorbed particles stabilising the peptide and peptide prodrug against plasma degradation and the particles adhering to the endothelial cells of the blood brain 
barrier, enabling the peptide and the peptide prodrug to cross the BBB (Figure 2) by as yet unclear cellular mechanisms (Garrett, Lalatsa et al. 2012; Lalatsa, Garrett et al. 2012; Siew, Le et al. 2012). In the case of formulations comprised of the prodrug, the drug is released from the prodrug by plasma, liver and possibly brain esterases (Lalatsa, Lee et al. 2012). Developing medicines from endogenous peptides does not require validation of the mechanism of action for the active therapeutic. This is critical if one wishes to avoid the high attrition rates in late clinical development as clinical proof-of concept data is already available. Although commercialisation of peptides as oral therapies is still deemed risky by the pharmaceutical industry, the rewards of niche treatment areas should fuel the development of peptide pill technologies by smaller market entrants.

\subsection{Intranasal Administration}

Nasal delivery is a promising alternative to intravenous injection for the delivery of peptides and proteins as the large surface area and high vascularity of the nasal cavity favours fast absorption of therapeutic molecules into the systemic circulation. However, peptide intranasal bioavailability is considerably less effective than after intravenous administration due to enzymatic degradation or mucociliary clearance, and poor mucosal membrane permeability of large polar substrates (Irwin, Dwivedi et al. 1994).

Exploitation of the nasal route for the delivery of drugs to the brain via the olfactory region has been explored as the olfactory region of the nose can be a major site for entry of viruses into the brain (Illum 2000; Reis, Veiga et al. 2008). In order for a peptide to travel from the olfactory region in the nasal cavity to the cerebrospinal fluid (CSF) or the brain parenchyma, it has to traverse the nasal olfactory epithelium and, depending on the pathway followed, also the arachnoid membrane surrounding the subarachnoid space. Three different pathways across the olfactory epithelium may be envisaged; a) a transcellular pathway, especially across the sustentacular cells, most likely by receptor mediated endocytosis, fluid 
phase endocytosis or by passive diffusion (unlikely for peptides), b) a paracellular pathway through tight junctions between the sustentacular cells and olfactory neurones and c) via the olfactory nerve pathway where the drug is taken up into the neurons by endocytotic or pinocytotic mechanisms and transported by intracellular axonal transport to the olfactory bulb (Illum 2000). The transneuronal pathway is very slow and agents reach the CNS as late as 24 hours after administration, hence transport via neuronal routes cannot explain the rapid appearance of drug in the CSF that is seen for a range of low molecular weight compounds (Illum 2000). Hence, at least in animal models, a therapeutic molecule with moderate lipophilicity, i.e. one that is not so lipophilic so as to give rapid transport into the systemic circulation, will show a higher CSF and olfactory bulb concentration after nasal administration than after parenteral administration (Illum 2000).

Leucine $^{5}$ - enkephalin loaded $\mathrm{N}$ - trimethyl chitosan nanoparticles prepared using the ionic gelation method were evaluated as a brain delivery vehicle via the nasal route. Using the $\mathrm{N}$ trimethyl chitosan gel nanoparticles, there was significant improvement in the observed antinociceptive effect of leucine ${ }^{5}$ - enkephalin, as evidenced by the hot plate and acetic acid induced writhing bioassay (Kumar, Pandey et al. 2013). Polysorbate 80 coated nanoparticles loaded with neurotoxin II (an analgesic peptide which was separated from the venom of Naja atra) also resulted in enhanced antinociception after intranasal delivery (Ruan, Yao et al. 2012).

Thyrotropin-releasing hormone $(\mathrm{TRH})$ is reported to have anticonvulsant effects in epileptic patients but is unable to cross the BBB and is rapidly metabolised in the periphery. The intranasal administration of $\mathrm{TRH}$ loaded poly $(\mathrm{D}, \mathrm{L}$ - lactic acid) nanoparticles reduced the frequency and severity of seizures in a rat seizure model. (Kubek, Domb et al. 2009; Veronesi, Aldouby et al. 2009).

Coating particles with brain endothelial cell transport ligands has also been explored via the 
intranasal route. Lactoferrin, a natural $80 \mathrm{kDa}$ iron binding cationic glycoprotein of the transferrin family, consists of a single-chain glycoprotein folded into two globular lobes and lactoferrin is expressed in various tissues and involved in various physiological processes, such as iron uptake by the intestinal mucosa and acting as a bacteriostatic agent (Lönnerdal and Iyer 1995; Suzuki, Lopez et al. 2005). Extensive histological studies revealed that the lactoferrin receptor is highly expressed in brain endothelial cells and neurons and overexpressed in the CNS in age-related neurodegenerative diseases including Alzheimer's Disease, Parkinson's disease, Huntington's disease and amyotrophic lateral sclerosis (Liu, Jiang et al. 2013). Furthermore, lactoferrin is more efficiently taken up by the brain tissue than both transferrin and OX26 (Ji, Maeda et al. 2006). The intranasal administration lactoferrin conjugated poly(ethylene glycol) - block - poly(epsilon caprolactone) (PEG - PCL) nanoparticles loaded with the neuroprotective peptide NAPVSIPQ produced superior results to NAPVSIPQ loaded onto plain PEG - PCL nanoparticles. Pharmacological activity was evaluated in a rat Morris water maze experiment (Liu, Jiang et al. 2013). The behavioural pharmacodynamic activity improvements were supported by the evaluation of acetylcholinesterase activity, choline acetyltransferase activity and neuronal degeneration in the mice hippocampus (Liu, Jiang et al. 2013).

Another successful nasal strategy involved PEG - PLA nanoparticles modified with wheat germ agglutinin loaded with vasoactive intestinal peptide. This formulation resulted in enhanced brain uptake and improvements in spatial memory in ethylcholine aziridium treated rats following the intranasal administration of $25 \mu \mathrm{g} \mathrm{kg}^{-1}$ and $12.5 \mu \mathrm{g} \mathrm{kg}^{-1}$ of vasoactive intestinal peptide loaded on unmodified nanoparticles and wheat germ agglutininmodified nanoparticles, respectively (Gao, Wu et al. 2007). An intranasal peptide delivery system was also developed by conjugation of odorranalectin (MW $=1700 \mathrm{Da}$, a leptin like peptide) to cubosomes via a non-covalent streptavidin - biotin "bridge". Odorranalectin retained its bio - recognitive activity and enhanced the nose to brain delivery of 
Gly ${ }^{14}$ Humanin (a neuroprotective peptide) (Wu, Li et al. 2012). Pharmacodynamics effects were measured in a Morris water maze test and by acetylcholinesterase activity $(\mathrm{Wu}, \mathrm{Li}$ et al. 2012).

TAT peptides have also been utilised via the intranasal route. TAT-NBD, a 22 amino-acid CPP containing the nuclear factor kappa $\mathrm{B}(\mathrm{NF}-\mathrm{KB}) \mathrm{IKK} \gamma$ - Binding Domain coupled to the transduction sequence of the HIV - TAT protein, is a potent NF- KB inhibitor that attenuates inflammatory responses (Yang, Sun et al. 2013). Yet, intravenous delivery of TAT - NBD peptides still requires a high dose to cross the BBB to reach the central nervous system; such a high dose may weaken general immunity and increase the risk of severe infection (Yang, Sun et al. 2013). In an attempt to reduce the required dose, intranasal delivery of TAT - NBD peptides was carried out in two animal models of neonatal infection sensitised hypoxic-ischemic brain injury. Kinetic experiments showed that TAT - NBD peptides entered the olfactory bulbs rapidly (within $10-30 \mathrm{~min}$ ) and peaked in the cerebral cortex around 60 min after the intranasal application in P7 rats (Yang, Sun et al. 2013). Further, intranasal delivery of $1.4 \mathrm{mg} \mathrm{kg}^{-1}$ TAT - NBD, which is only $7 \%$ of the intravenous dose, markedly attenuated NF- KB signalling, microglia activation, and the brain damage triggered by hypoxic ischemia (following a 4 or $72 \mathrm{~h}$ exposure to the bacterial endotoxin lipopolysaccharide) (Yang, Sun et al. 2013).

Intranasal to the brain peptide delivery strategies have not only been the subject of preclinical experiments but have been exploited in clinical studies and even resulted in the launch of peptide products. Peptides such as melanocortin (4-10), angiotensin II, argininevasopressin, cholecystokinin - 8, oxytocin and insulin have been successfully delivered to the brain in human trials (Table 2). However, recently Allon Therapeutics Inc. announced that its drug candidate davunetide [NAP, eight amino acid peptide (NAPVSIPQ)] failed to show efficacy for progressive supranuclear palsy (PSP) in a phase $2 / 3$ trial. Participants 
showed no benefit on either of the primary outcome measures, the progressive supranuclear palsy rating scale and the Schwab and England Activities of Daily Living and neither secondary endpoints either (ClinicaSpace 2012).

Table 3 Summary of clinical studies of nasal delivery of peptides to CNS

\begin{tabular}{|c|c|c|c|c|}
\hline Peptide & $\begin{array}{l}\text { Molecular } \\
\text { Weight (Da) }\end{array}$ & Pharmacokinetics & Pharmacodynamics & References \\
\hline $\begin{array}{l}\text { Melanocortin (4 - } \\
\text { 10) }\end{array}$ & 980 & Detected in CSF & $\begin{array}{l}\text { Acutely diminished } \\
\text { focusing of attention, } \\
\text { decreased body - fat in } \\
\text { normal weight humans }\end{array}$ & $\begin{array}{l}\text { (Born, Lange et } \\
\text { al. 2002), (Fehm, } \\
\text { Smolink et al. } \\
\text { 2001), (Smolnik, } \\
\text { Perras et al. } \\
\text { 2000), } \\
\text { (Hallschmid, } \\
\text { Smolnik et al. } \\
2006)\end{array}$ \\
\hline Angiotensin II & 1084 & Not determined & $\begin{array}{l}\text { Acutely increased blood } \\
\text { pressure }\end{array}$ & $\begin{array}{l}\text { (Derad, Willeke } \\
\text { et al. 1998) }\end{array}$ \\
\hline $\begin{array}{l}\text { Arginine - } \\
\text { vasopressin }\end{array}$ & 1046 & Detected in CSF & Enhanced brain activity & $\begin{array}{l}\text { (Pietrowsky, } \\
\text { Struben et al. } \\
\text { 1996) }\end{array}$ \\
\hline $\begin{array}{l}\text { Cholecystokinin - } \\
8\end{array}$ & 1143 & Not determined & Enhanced brain activity & $\begin{array}{l}\text { (Pietrowsky, } \\
\text { Thiemann et al. } \\
\text { 1996) }\end{array}$ \\
\hline Oxytocin & 1007 & Not determined & $\begin{array}{l}\text { Increased trust, reduce } \\
\text { stress-related control, }\end{array}$ & $\begin{array}{l}\text { (Kosfeld, } \\
\text { Heinrichs et al. }\end{array}$ \\
\hline
\end{tabular}




\begin{tabular}{|c|c|c|c|c|}
\hline & & & $\begin{array}{l}\text { produced anxiolytic } \\
\text { effects, attenuated } \\
\text { response to fear in } \\
\text { amygdala in } \\
\text { generalised anxiety } \\
\text { disorder, improved } \\
\text { emotional recognition in } \\
\text { autism }\end{array}$ & $\begin{array}{l}\text { 2005), (Kirsch, } \\
\text { Esslinger et al. } \\
\text { 2005), (Domes, } \\
\text { Heinrichs et al. } \\
\text { 2007), (Heinrichs, } \\
\text { Baurngartner et } \\
\text { al. } \\
\text { (Labuschange, } \\
\text { Phan et al. 2010), } \\
\text { (Guastella, } \\
\text { Einfeld et al. } \\
\text { 2010) }\end{array}$ \\
\hline Insulin & 5808 & Detected in CSF & $\begin{array}{l}\text { Reduced brain activity, } \\
\text { decreased food intake, } \\
\text { enhanced postprandial } \\
\text { thermogenesis, } \\
\text { improved memory and } \\
\text { modulated Ab in } \\
\text { patients with mild } \\
\text { cognitive impairment }\end{array}$ & $\begin{array}{l}\text { (Kern, Born et al. } \\
\text { 1999), (Benedict, } \\
\text { Hallschmid et al. } \\
\text { 2004), (Benedict, } \\
\text { Kern et al. 2008), } \\
\text { (Benedict, Brede } \\
\text { et al. 2011), } \\
\text { (Reger, Watson } \\
\text { et al. 2008) }\end{array}$ \\
\hline
\end{tabular}

\subsection{Concluding Remarks}

Over the last decade there have been significant advances in the delivery of peptides, to the brain. Various vectors have been shown to deliver peptides across the BBB with notable 
promise offered by receptor mediated endocytosis strategies such as the Angiopep peptides pioneered by Angiochem and transferrin antibodies developed by Armagen. The chitosan amphiphile nanoparticles developed by Nanomerics, cell penetrating peptides and the utilisation of nose to brain strategies by a number of companies are also recording notable successes. Protecting intravenous peptides from plasma degradation is a key to achieving brain delivery of these molecules on intravenous administration. With respect to the oral route, data has been presented on the oral delivery of peptides to the brain by utilising chitosan amphiphile nanoparticles that are taken up by the gastrointestinal epithelium. Controlling neurological conditions will continue to be at the forefront of therapeutic strategies for the foreseeable future. The possibility of delivering medicines containing drug compounds that do not usually distribute to the brain, by using the technologies and approaches described above, means that new medicines will emerge to tackle these rather challenging conditions.

\section{References}

Abbott, N. J., A. A. Patabendige, et al. Structure and function of the blood-brain barrier. Neurobiol Dis 2010, 37, (1), 13-25.

Adenot, M., P. Merida, et al. Applications of a blood-brain barrier technology platform to predict CNS penetration of various chemotherapeutic agents. 2. Cationic peptide vectors for brain delivery. Chemotherapy 2007, 53, (1), 73-76.

Aktas, Y., M. Yemisci, et al. Development and brain delivery of chitosan-PEG nanoparticles functionalized with the monoclonal antibody OX26. Bioconjug Chem 2005, 16, (6), 15031511.

Aliautdin, R. N., V. E. Petrov, et al. Transport of the hexapeptide dalargin across the hematoencephalic barrier into the brain using polymer nanoparticles. Eksp Klin Farmakol. 1996, 59, (3), 57-60.

Banks, W. A. Anorectic effects of circulating cytokines: role of the vascular blood-brain barrier. Nutrition 2001, 17, (5), 434-437.

Banks, W. A. Leptin transport across the blood-brain barrier: implications for the cause and treatment of obesity. Curr Pharm Des 2001, 7, (2), 125-133.

Banks, W. A., S. A. Farr, et al. Intravenous human interleukin-1alpha impairs memory processing in mice: dependence on blood-brain barrier transport into posterior division of the septum. $J$ Pharmacol Exp Ther 2001, 299, (2), 536-541.

Banks, W. A. and C. L. Farrell. Impaired transport of leptin across the blood-brain barrier in obesity is acquired and reversible. Am J Physiol Endocrinol Metab 2003, 285, (1), E10-15.

Banks, W. A. and A. J. Kastin. Opposite direction of transport across the blood-brain barrier for TyrMIF-1 and MIF-1: comparison with morphine. Peptides 1994, 15, 23-29. 
Batrakova, E. V., S. V. Vinogradov, et al. Polypeptide point modifications with fatty acid and amphiphilic block copolymers for enhanced brain delivery. Bioconjug Chem 2005, 16, (4), 793-802.

Benedict, C., S. Brede, et al. Intranasal serum insulin levels in healthy men. Diabetes 2011, 60, 114118.

Benedict, C., M. Hallschmid, et al. Intranasal insulin improves memory in humans. Psychoneuroendocrinology 2004, 29, 1326-1334.

Benedict, C., W. Kern, et al. Differential sensitivity of men and women to anorexigenic and memoryimproving effects of inranasal insulin. J Clin. Endocrinol. Metab. 2008, 93, 1339-1344.

Bertrand, Y., J. C. Currie, et al. Transport characteristics of a novel peptide platform for CNS therapeutics. J Cell Mol Med 2010, 14, (12), 2827-2839.

Bidwell, G. L., 3rd, E. Perkins, et al. Thermally targeted delivery of a c-Myc inhibitory polypeptide inhibits tumor progression and extends survival in a rat glioma model. PLoS One 2013, 8, (1), e55104.

Bilsky, E. J., R. D. Egleton, et al. Enkephalin glycopeptide analogues produce analgesia with reduced dependence liability. J Med Chem 2000, 43, (13), 2586-2590.

Born, J., T. Lange, et al. Sniffing neuropeptides: a transnasal approach to the human brain. Nature Neuroscience 2002, 6, (514-516).

Brasnjevic, I., H. W. Steinbusch, et al. Delivery of peptide and protein drugs over the blood-brain barrier. Prog Neurobiol 2009, 87, (4), 212-251.

Broadwell, R. D., B. J. Balin, et al. Transcytotic pathway for blood-borne protein through the bloodbrain barrier. Proc Natl Acad Sci U S A 1988, 85, (2), 632-636.

Burgueraa, B. and M. E. Couceb. Leptin access into the brain: A saturated transport mechanism in obesity. Physiol Behav 2001, 74, (4-5), 717-720.

Cacciatore, I., L. Baldassarre, et al. Recent advances in the treatment of neurodegenerative diseases based on GSH delivery systems. Oxid Med Cell Longev 2012, 240146.

Chang, W. P., G. Koelsch, et al. In vivo inhibition of Abeta production by memapsin 2 (betasecretase) inhibitors. J Neurochem 2004, 89, (6), 1409-1416.

Chen, J., T. J. Falla, et al. Development of protegrins for the treatment and prevention of oral mucositis: structure-activity relationships of synthetic protegrin analogues. Biopolymers $\mathbf{2 0 0 0}$, 55, 88-98.

ClinicaSpace Allon Therapeutics, Inc. Announces PSP Clinical Trial Results. http://www.clinicaspace.com/news story.aspx?NewsEntityId=282772\&type=email\&source= CS_121912 (2nd November),

Cui, H., M. J. Webber, et al. Self-assembly of peptide amphiphiles: from molecules to nanostructures to biomaterials. Biopolymers 2010, 94, (1), 1-18.

Das, D. and S. Lin. Double-coated poly (butylcynanoacrylate) nanoparticulate delivery systems for brain targeting of dalargin via oral administration. J Pharm Sci 2005, 94, (6), 1343-1353.

Demeule, M., J. C. Currie, et al. Involvement of the low-density lipoprotein receptor-related protein in the transcytosis of the brain delivery vector angiopep-2. J Neurochem 2008, 106, (4), 15341544.

Demeule, M., J. Poirier, et al. High transcytosis of melanotransferrin (P97) across the blood-brain barrier. J Neurochem 2002, 83, (4), 924-933.

Demeule, M., A. Regina, et al. Identification and design of peptides as a new drug delivery system for the brain. J Pharmacol Exp Ther 2008, 324, (3), 1064-1072.

Demeule, M., A. Regina, et al., ANG2002: A new Angiochem-modified neurotensin with increased brain penetration and analgesic properties (374.11/QQ6). In Society for Neurosciences Annual Meeting, Neuroscience Meeting Planner: San Diego, CA, 2010.

Derad, I., K. Willeke, et al. Intranasal angiotensin II directly influences central nervous regulation of blood pressure. Am J Hypertens 1998, 11, (971-977).

Domes, G., M. Heinrichs, et al. Oxytocin improves "mind-reading" in humans. Biol. Psychiatry 2007, 61, 731-733. 
Drin, G., S. Cottin, et al. Studies on the internalization mechanism of cationic cell-penetrating peptides. J Biol Chem 2003, 278, (33), 31192-31201.

Duffy, K. R., W. M. Pardridge, et al. Human blood-brain barrier insulin-like growth factor receptor. Metabolism 1988, 37, (2), 136-140.

Egleton, R. D., S. A. Mitchell, et al. Improved bioavailability to the brain of glycosylated Metenkephalin analogs. Brain Res 2000, 881, (1), 37-46.

Eiriksdottira, E., K. Konateb, et al. Secondary structure of cell-penetrating peptides controls membrane interaction and insertion. Biochim Biophys Acta-Biomembranes 2010, 1798, (6), 1119-1128.

Erazo-Oliveras, A., N. Muthukrishnan, et al. Improving the Endosomal Escape of Cell-Penetrating Peptides and Their Cargos: Strategies and Challenges. Pharmaceuticals 2012, 5, 1177-1209.

Fehm, H. L., R. Smolink, et al. The melonocortin melanocyte-stimulating hormone/adrenocorticotropin (4-10) decreases body fat in humans. J Clin Endocrinol Metabol 2001, 86, (1144-48).

Fishman, J. B., J. B. Rubin, et al. Receptor-mediated transcytosis of transferrin across the blood-brain barrier. J Neurosci Res 1987, 18, (2), 299-304.

Frank, H. J. and W. M. Pardridge. A direct in vitro demonstration of insulin binding to isolated brain microvessels. Diabetes 1981, 30, (9), 757-761.

Frank, H. J., W. M. Pardridge, et al. Binding and internalization of insulin and insulin-like growth factors by isolated brain microvessels. Diabetes 1986, 35, (6), 654-661.

Gabathuler, R. Approaches to transport therapeutic drugs across the blood-brain barrier to treat brain diseases. Neurobiol Dis 2010, 37, (1), 48-57.

Gaillard, P. J., A. Brink, et al. Diphtheria toxin receptor-targeted brain drug delivery. Int. Congr. Ser. 2005, 1277, 185-198.

Gaillard, P. J. and A. G. de Boer. A novel opportunity for targeted drug delivery to the brain. $J$ Control Release 2006, 116, (2), e60-62.

Gao, X., B. Wu, et al. Brain delivery of vasoactive intestinal peptide enhanced with the nanoparticles conjugated with wheat germ agglutinin following intranasal administration. $J$ Control Release 2007, 121, (3), 156-167.

Garrett, N. L., A. Lalatsa, et al. Exploring uptake mechanisms of oral nanomedicines using multimodal nonlinear optical microscopy. J Biophotonics 2012, 5, (5-6), 458-468.

Gozes, I., I. Divinski, et al. NAP and D-SAL:neuroprotection against the beta amyloid peptide (1-42). BMC Neurosci 2008, 9, (Suppl 3), S3.

Guastella, A. J., S. L. Einfeld, et al. Intranasal oxytocin improves emotion recognition for youth with autism spectrum disorders. Biol. Psychiatry 2010, 67, 692-694.

Hallschmid, M., R. Smolnik, et al. Overweight humans are resistant to the weight-reducing effects of melanocortin 4-10. J Clin Endocrinol Metab 2006, 91, (522-525).

Harwig, S. S. L., A. Waring, et al. Intramolecular Disulfide Bonds Enhance the Antimicrobial and Lytic Activities of Protegrins at Physiological Sodium Chloride Concentrations. Eur J Biochem 1996, 240, 352-357.

Heinrichs, M., T. Baurngartner, et al. Social support and oxytocin interact to suppress cortisol and subjective responses to psychosocial stress. . . Biol. Psychiatry 2003, 54, 1389-1398.

Herve, F., N. Ghinea, et al. CNS delivery via adsorptive transcytosis. AAPS J 2008, 10, (3), 455-472.

Herz, J. and P. Marschang. Coaxing the LDL receptor family into the fold. Cell 2003, 112, (3), 289292.

Illum, L. Transport of drugs from the nasal cavity to the central nervous system. Eur J Pharm Sci 2000, 11, (1), 1-18.

Irwin, W. J., A. K. Dwivedi, et al. The effect of cyclodextrins on the stability of peptides in nasal enzymic systems. Pharm Res 1994, 11, (12), 1698-1703.

Jefferies, W. A., M. R. Brandon, et al. Transferrin receptor on endothelium of brain capillaries. Nature 1984, 312, (5990), 162-163.

Ji, B., J. Maeda, et al. Pharmacokinetics and brain uptake of lactoferrin in rats. Life Sci 2006, 78, 
$851 \mathrm{e} 855$.

Kelder, J., P. D. Grootenhuis, et al. Polar molecular surface as a dominating determinant for oral absorption and brain penetration of drugs. Pharm Res 1999, 16, (10), 1514-1519.

Kern, W., J. Born, et al. Central nervous system effects of intranasally administered insulin during euglycemia in men. . Diabetes 1999, 48, 557-563.

Kirsch, P., C. Esslinger, et al. Oxytocin modulates neural circuitry for social cognition and fear in humans. . J Neurosci 2005, 25 11489-11493.

Kosfeld, M., M. Heinrichs, et al. Oxytocin increases trust in humans. Nature 2005, 435, 673-676.

Kubek, M. J., A. J. Domb, et al. Attenuation of kindled seizures by intranasal delivery of neuropeptide-loaded nanoparticles. Neurotherapeutics 2009, 6, (2), 359-371.

Kumar, M., R. S. Pandey, et al. Evaluation of neuropeptide loaded trimethyl chitosan nanoparticles for nose to brain delivery. Int J Biol Macromol 2013, 61, (C), 189-195.

Labuschange, I., K. L. Phan, et al. Oxytocin attenuates amygdala reactivity to fear in generalised social anxiety disorder. . Neuropsychopharmacology 2010, 35, 2403-2413.

Lalatsa, A., N. Garrett, et al. Delivery of peptides to the blood and brain after oral uptake of quaternary ammonium palmitoyl glycol chitosan nanoparticles. Mol. Pharm. 2012, 9, (6), 1764-1774.

Lalatsa, A., N. L. Garrett, et al. Delivery of peptides to the blood and brain after oral uptake of quaternary ammonium palmitoyl glycol chitosan nanoparticles. Mol Pharm 2012, 9, (6), 1764-1774.

Lalatsa, A., V. Lee, et al. A prodrug nanoparticle approach for the oral delivery of a hydrophilic peptide, leucine(5)-enkephalin, to the brain. Mol Pharm 2012, 9, (6), 1665-1680.

Lalatsa, A., Schätchlein AG, Uchegbu IF, Drug Delivery across the Blood-brain barrier. In Comprehensive Biotechnology 2nd ed.; M. Moo-Young, Butler M, Webb C, Moreira A, Grodzinski B, Cui Z, Ed. Elsevier: Amsterdam, 2011; pp 657-668.

Lalatsa, A., A. G. Schatzlein, et al. Chitosan Amphiphile Coating of Peptide Nanofibres Reduces Liver Uptake and Delivers the Peptide to the Brain on Intravenous Administration. Biomaterials 2013, Submitted.

Lalatsa, A., A. G. Schatzlein, et al., Chapter 7.1: Nanostructures Overcoming the Blood-Brain Barrier: Physiological Considerations and Mechanistic Issues In Nanostructured Biomaterials for Overcoming Biological Barriers, M. J. Alonso and N. Csaba, Eds. Royal Society of Chemistry: London, 2012; pp 329-363.

Lax, R. The future of peptide development in the pharmaceutical industry. PharManufacturing: The International Peptide Review 2010.

Lennernas, H. and E. Lundgren. Intestinal and blood-brain drug transport: beyond involvement of a single transport function. Drug Discovery Today: Technologies 2004, 1, (4), 417-422.

Li, F. Q., G. D. Sempowski, et al. Apolipoprotein E-derived peptides ameliorate clinical disability and inflammatory infiltrates into the spinal cord in a murine model of multiple sclerosis. $J$ Pharmacol Exp Ther 2006, 318, (3), 956-965.

Lindqvist, A., J. Rip, et al. Enhanced brain delivery of the opioid peptide DAMGO in glutathione pegylated liposomes: a microdialysis study. Mol Pharm 2013, 10, (5), 1533-1541.

Liu, L., K. Xu, et al. Self-assembled cationic peptide nanoparticles as an efficient antimicrobial agent. Nat Nanotechnol 2009, 4, (7), 457-463.

Liu, Y., M. Jones, et al. Uptake of HIV-1 tat protein mediated by low-density lipoprotein receptorrelated protein disrupts the neuronal metabolic balance of the receptor ligands. Nat Med 2000, 6, 1380-1387.

Liu, Z., X. Gao, et al. B6 Peptide-Modified PEG-PLA Nanoparticles for Enhanced Brain Delivery of Neuroprotective Peptide. Bioconjug Chem 2013, 24, (6), 997-1007.

Liu, Z., M. Jiang, et al. Lactoferrin-modified PEG-co-PCL nanoparticles for enhanced brain delivery of NAP peptide following intranasal administration. Biomaterials 2013, 34, (15), 3870-3881.

Lönnerdal, B. and S. Iyer. Lactoferrin: molecular structure and biological function. Annu Rev Nutr. 1995, (15). 
Malcor, J. D., N. Payrot, et al. Chemical optimization of new ligands of the low-density lipoprotein receptor as potential vectors for central nervous system targeting. J Med Chem 2012, 55, (5), 2227-2241.

Mangoni, M. E., A. Aumelas, et al. Change in membrane permeability induced by protegrin 1: implication of disulphide bridges for pore formation. FEBS Lett 1996, 383, (1-2), 93-98.

Masserini, M. Nanoparticles for Brain Drug Delivery. ISRN Biochemistry 2013, Article 238428, 1-18.

Mazza, M., R. Notman, et al. Nanofiber-based delivery of therapeutic peptides to the brain. ACS Nano 2013, 7, (2), 1016-1026.

Mishra, V., S. Mahor, et al. Targeted brain delivery of AZT via transferrin anchored pegylated albumin nanoparticles. J Drug Target 2006, 14, (1), 45-53.

Mitchell, D. J., L. Steinman, et al. Polyarginine enters cells more efficiently than other polycationic homopolymers. J Pept Res 2000, 56, 318-325.

Morris, M. C., S. Deshayes, et al. Cell-penetrating peptides: from molecular mechanisms to therapeutics. Biol. Cell 2008, 100, 201-217.

Nance, E. A., G. F. Woodworth, et al. A dense poly(ethylene glycol) coating improves penetration of large polymeric nanoparticles within brain tissue. Sci Transl Med 2012, 4, (149), 149 ra119.

Nikolich, K., Taking novel therapeutics to the brain: biologics. In 39th meeting of the Society for Neuroscience, Chicago, 2009.

Pan, W. and A. J. Kastin. Entry of EGF into brain is rapid and saturable. Peptides 1999, 20, (9), 1091-1098.

Pan, W. and A. J. Kastin. TNFalpha transport across the blood-brain barrier is abolished in receptor knockout mice. Exp Neurol 2002, 174, (2), 193-200.

Pang, Z., W. Lu, et al. Preparation and brain delivery property of biodegradable polymersomes conjugated with OX26. J Control Release 2008, 128, (2), 120-127.

Paramonov, S. E., H. W. Jun, et al. Self-assembly of peptide-amphiphile nanofibers: the roles of hydrogen bonding and amphiphilic packing. J Am Chem Soc 2006, 128, (22), 7291-7298.

Pardridge, W. M. The blood-brain barrier: bottleneck in brain drug development. NeuroRx 2005, 2, (1), 3-14.

Pardridge, W. M. Drug transport across the blood-brain barrier. J Cereb Blood Flow Metab 2012, 32, (11), 1959-1972.

Pardridge, W. M. and R. J. Boado Fusion proteins for blood-brain barrier delivery. 2007.

Pardridge, W. M. and R. J. Boado Agents for blood-brain barrier delivery. 2008.

Pardridge, W. M. and R. J. Boado Methods and compositions for increasing alpha-iduronidase activity in the CNS 2009.

Pardridge, W. M. and R. J. Boado Fusion proteins for delivery of GDNF to the CNS. 2010.

Pardridge, W. M. and R. J. Boado. Reengineering biopharmaceuticals for targeted delivery across the blood-brain barrier. Methods Enzymol 2012, 503, 269-292.

Pauletti, G. M., F. W. Okumu, et al. Effect of size and charge on the passive diffusion of peptides across Caco-2 cell monolayers via the paracellular pathway. Pharm Res 1997, 14, (2), 164168.

Pietrowsky, R., C. Struben, et al. Brain potential changes after intranasal vs. intravenous administration of vasopressin: evidence for a direct nose-brain pathway for peptide effects in humans. Biol. Psychiatry 1996, 39, (332-340).

Pietrowsky, R., A. Thiemann, et al. A nose-brain pathway for psychotropic peptides: evidence from a brain evoked potential study with cholecystokinin. Psychoneuroendocrinology 1996, 21, (559-572).

Popov, M., I. Abu Hammad, et al. Delivery of analgesic peptides to the brain by nano-sized bolaamphiphilic vesicles made of monolayer membranes. Eur J Pharm Biopharm 2013, Ehead of Publication, S0939-6411.

Reger, M. A., G. S. Watson, et al. Intranasal insulin improves cognition and modulates beta-amyloid in early AD. Neurology 2008, 70, 440-448.

Regina, A., M. Demeule, et al. Antitumour activity of ANG1005, a conjugate between paclitaxel and 
the new brain delivery vector Angiopep-2. Br J Pharmacol 2008, 155, (2), 185-197.

Reichert, J. (2010) "2010 Development trends for peptide therapeutics: A comprehensive quantitative analysis of peptide therapeutics in clinical development."

Reis, C. P., F. J. Veiga, et al. Nanoparticulate biopolymers deliver insulin orally eliciting pharmacological response. J Pharm Sci 2008, 97, (12), 5290-5305.

Rousselle, C., P. Clair, et al. Improved brain uptake and pharmacological activity of dalargin using a peptide-vector-mediated strategy. J Pharmacol Exp Ther 2003, 306, (1), 371-376.

Ruan, Y., L. Yao, et al. Nanoparticle-mediated delivery of neurotoxin-II to the brain with intranasal administration: an effective strategy to improve antinociceptive activity of neurotoxin. Drug Dev Ind Pharm 2012, 38, (1), 123-128.

Rusnati, M., D. Coltrini, et al. Interaction of HIV-1 Tat protein with heparin. J Biol Chem 1997, 272, 11313-11320.

Sabel B. A. and S. U. Drug Targeting system, method of its preparation and its use. 1997.

Schroeder, U., P. Sommerfeld, et al. Efficacy of oral dalargin-loaded nanoparticle delivery across the blood-brain barrier. Peptides 1998, 19, (4), 777-780.

Serrano Lopez, D. R. and A. Lalatsa. Peptide pills for brain diseases? Reality and future perspectives. Ther Deliv 2013, 4, (4), 479-501.

Siew, A., H. Le, et al. Enhanced oral absorption of hydrophobic and hydrophilic drugs using quaternary ammonium palmitoyl glycol chitosan nanoparticles. Mol Pharm 2012, 9, (1), 1428.

Smolnik, R., B. Perras, et al. Event-related brain potentials and working memory function in healthy humans after single-dose and prolonged intranasal administration of adrenocorticotropin 4-10 and desacetyl-alpha-melanocyte stimulating hormone. J Clin Psychopharmacol 2000, 20, (445-454).

Sorensen, M., B. Steenberg, et al. The effect of beta-turn structure on the permeation of peptides across monolayers of bovine brain microvessel endothelial cells. Pharm Res 1997, 14, (10), 1341-1348.

Strand, F. L., Neuropeptides: general characteristics and neuropharmaceutical potential in treating CNS disorders. In Progress in Drug Research: Peptide Transport and Delivery into the Central Nervous System, L. a. P.-T. Prokai, K., Ed. Birkhäuser Basel: Basel, 2003; Vol. 31, pp 1-37.

Subrizi, A., E. Tuominenb, et al. Tat(48-60) peptide amino acid sequence is not unique in its cell penetrating properties and cell-surface glycosaminoglycans inhibit its cellular uptake. $J$ Control Release 2013, 158, (2), 277-285.

Suzuki, Y. A., V. Lopez, et al. Mammalian lactoferrin receptors: structure and function. Cell Mol Life Sci. 2005, 62, (22), 2560-2575.

Teixido, M., I. Belda, et al. Evolutionary combinatorial chemistry, a novel tool for SAR studies on peptide transport across the blood-brain barrier. Part 2. Design, synthesis and evaluation of a first generation of peptides. J Pept Sci 2005, 11, (12), 789-804.

Thomas, F. C., K. Taskar, et al. Uptake of ANG1005, a novel paclitaxel derivative, through the blood-brain barrier into brain and experimental brain metastases of breast cancer. Pharm Res 2009, 26, (11), 2486-2494.

Tian, X. H., F. Wei, et al. In vitro and in vivo studies on gelatin-siloxane nanoparticles conjugated with SynB peptide to increase drug delivery to the brain. Int J Nanomedicine 2012, 7, 10311041.

Tosi, G., L. Badiali, et al. Can leptin-derived sequence-modified nanoparticles be suitable tools for brain delivery? Nanomedicine (Lond) 2012, 7, (3), 365-382.

Tünnemann, G. and M. C. Cardoso, Cell-Penetrating Peptides Uptake, Toxicity, and Applications. In Membrane-Active peptides: methods and results on structure and function., M. Castanho, Ed. IUL Publishers: La Jolla, California, 2009; pp 331-362.

Uchegbu, I. F. and A. Siew. Nanomedicines and nanodiagnostics come of age. J Pharm. Sci. 2013, $102,305-310$. 
Ulbrich, K., T. Hekmatara, et al. Transferrin- and transferrin-receptor-antibody-modified nanoparticles enable drug delivery across the blood-brain barrier (BBB). Eur J Pharm Biopharm 2009, 71, (2), 251-256.

Ulijn, R. V. and A. M. Smith. Designing peptide based nanomaterials. Chem Soc Rev 2008, 37, (4), 664-675.

van Houten, M., B. I. Posner, et al. Insulin-binding sites in the rat brain: in vivo localization to the circumventricular organs by quantitative radioautography. Endocrinology 1979, 105, (3), 666673.

van Rooy, I., E. Mastrobattista, et al. Comparison of five different targeting ligands to enhance accumulation of liposomes into the brain. J Control Release 2011, 150, (1), 30-36.

Veronesi, M. C., Y. Aldouby, et al. Thyrotropin-releasing hormone d,l polylactide nanoparticles (TRH-NPs) protect against glutamate toxicity in vitro and kindling development in vivo. Brain Res 2009, 1303, 151-160.

Visser, C. C., S. Stevanovic, et al. Validation of the transferrin receptor for drug targeting to brain capillary endothelial cells in vitro. J Drug Target 2004, 12, (3), 145-150.

Visser, C. C., L. H. Voorwinden, et al. Characterization and modulation of the transferrin receptor on brain capillary endothelial cells. Pharm Res 2004, 21, (5), 761-769.

Vlieghe, P. and M. Khrestchatisky. Peptide-based vectors for blood-brain barrier targeting and delivery of drugs to the central nervous system. Ther Deliv 2010, 1, (4), 489-494.

Vlieghe, P., V. Lisowski, et al. Synthetic therapeutic peptides: science and market. Drug Discov. Today 2010, 15, (1-2), 40-56.

Wender, P. A., D. J. Mitchell, et al. The design, synthesis, and evaluation of molecules that enable or enhance cellular uptake: peptoid molecular transporters. Proc Natl Acad Sci U S A 2000, 97, (24), 13003-13008.

Willingham, M. C., J. A. Hanover, et al. Morphologic characterization of the pathway of transferrin endocytosis and recycling in human KB cells. Proc Natl Acad Sci U S A 1984, 81, (1), 175179.

$\mathrm{Wu}, \mathrm{H} ., \mathrm{J} . \mathrm{Li}$, et al. A novel small Odorranalectin-bearing cubosomes: preparation, brain delivery and pharmacodynamic study on amyloid- $\beta_{25-35}$-treated rats following intranasal administration. Eur J Pharm Biopharm 2012, 80, (2), 368-378.

Xia, H., X. Gao, et al. Penetratin-functionalized PEG-PLA nanoparticles for brain drug delivery. Int $J$ Pharm 2012, 436, (1-2), 840-850.

Yang, D., Y. Y. Sun, et al. Intranasal delivery of cell-penetrating anti-NF-kB peptides (Tat-NBD) alleviates infection-sensitized hypoxic-ischemic brain injury. Exp Neurol 2013, 247, 447-455.

Zhang, S., T. Holmes, et al. Spontaneous assembly of a self-complementary oligopeptide to form a stable macroscopic membrane. Proc Natl Acad Sci U S A 1993, 90, (8), 3334-3338.

Zhang, S., D. M. Marini, et al. Design of nanostructured biological materials through self-assembly of peptides and proteins. Curr Opin Chem Biol 2002, 6, (6), 865-871.

Zhou, J., T. R. Patel, et al. Highly penetrative, drug-loaded nanocarriers improve treatment of glioblastoma. Proc Natl Acad Sci U S A 2013, 110, (29), 11751-11756.

Zlokovic, B. V., D. S. Skundric, et al. A saturable mechanism for transport of immunoglobulin G across the blood-brain barrier of the guinea pig. Exp Neurol 1990, 107, (3), 263-270. 